\title{
Deposition of metal chalcogenide thin films by successive ionic layer adsorption and reaction (SILAR) method
}

\author{
H M PATHAN and C D LOKHANDE* \\ Department of Physics, Shivaji University, Kolhapur 416 004, India
}

MS received 16 May 2002; revised 15 December 2003

\begin{abstract}
During last three decades, successive ionic layer adsorption and reaction (SILAR) method, has emerged as one of the solution methods to deposit a variety of compound materials in thin film form. The SILAR method is inexpensive, simple and convenient for large area deposition. A variety of substrates such as insulators, semiconductors, metals and temperature sensitive substrates (like polyester) can be used since the deposition is carried out at or near to room temperature. As a low temperature process, it also avoids oxidation and corrosion of the substrate. The prime requisite for obtaining good quality thin film is the optimization of preparative provisos viz. concentration of the precursors, nature of complexing agent, $\mathrm{pH}$ of the precursor solutions and adsorption, reaction and rinsing time durations etc.

In the present review article, we have described in detail, successive ionic layer adsorption and reaction (SILAR) method of metal chalcogenide thin films. An extensive survey of thin film materials prepared during past years is made to demonstrate the versatility of SILAR method. Their preparative parameters and structural, optical, electrical properties etc are described. Theoretical background necessary for the SILAR method is also discussed.
\end{abstract}

Keywords. Metal chalcogenides; thin solid films; SILAR method.

\section{Introduction}

Any solid or liquid system possesses at most two-dimensional order of periodicity called 'thin film'. Properties of thin film often differ significantly from those of bulk due to surface and interface effects, which may dominate the overall behaviour of these films. Thin films are of particular interest for fabrication of large area arrays, solar selective coatings, solar cells, photoconductors, sensors, antireflection coatings, interference items, polarizers, narrow band filters, IR detectors, wave guide coatings, temperature control of satellites, photothermal solar coatings etc. Thin films can be fabricated in various ways. The techniques can be divided into physical and chemical methods. In physical methods, the film material is moved from a target source with some form of energy to the substrate. This method is widely used in one-compound films, like metal films. Under physical methods we have vacuum evaporation and sputtering, where the deposition has been transferred to gaseous state either by evaporation or an impact process. Chemical film fabrication method involves chemical reaction and the precursors are mostly components undergoing reaction at the substrate surface or in the vicinity of the substrate. Under chemical methods we have the gas phase chemical processes such as

\footnotetext{
*Author for correspondence
}

conventional chemical vapour deposition (CVD), laser CVD, metal organochemical deposition (MOCVD) and plasma enhanced chemical vapour deposition. Liquid phase chemical techniques include electrodeposition, chemical bath deposition, electroless deposition, anodization, spray pyrolysis etc.

One of the newest solution methods for the deposition of thin film is successive ionic layer adsorption and reaction (SILAR) method, which is also known as modified version of chemical bath deposition. In spite of its simplicity, SILAR has a number of advantages: (i) it offers extremely easy way to dope film with virtually any element in any proportion by merely adding it in some form of the cationic solution, (ii) unlike closed vapour deposition method, SILAR does not require high quality target and/or substrates nor does it require vacuum at any stage, which is a great advantage if the method will be used for industrial application, (iii) the deposition rate and the thickness of the film can be easily controlled over a wide range by changing the deposition cycles, (iv) operating at room temperature can produce films on less robust materials, (v) unlike high power methods such as radio frequency magnetron sputtering (RFMS), it does not cause local over heating that can be detrimental for materials to be deposited and (vi) there are virtually no restrictions on substrate material, dimensions or its surface profile. Moreover, it is relatively inexpensive, simple and convenient for large area deposition. It can be carried out in 
glass beakers. The starting materials are commonly available and cheap materials. As it is a chemical method, a large number of varieties of substrates can be coated. Thus, any insoluble surface to which the solution has free access will be a suitable substrate for the deposition. The deposition is carried out at or close to room temperature, avoids oxidation or corrosion of metallic substrates. Stoichiometric deposit is easily obtained. Since the basic building blocks are ions instead of atoms, the preparative parameters are easily controllable and better orientation and improved grain structure can be obtained.

In chemical bath deposition (CBD) method, deposition of metal chalcogenide semiconducting thin films occurs due to substrate maintained in contact with dilute chemical bath containing metal and chalcogen ions. The film formation on substrate takes place when ionic product exceeds solubility product. However, this results into precipitate formation in the bulk of solution, which cannot be eliminated. This results in unnecessary formation of precipitation and loss of material. In order to avoid such unnecessary precipitation, a CBD is modified and known as successive ionic layer adsorption and reaction (SILAR) method. In this modification, thin films are obtained by immersing substrate into separately placed cationic and anionic precursors and rinsing between every immersion with ion-exchanged water. The rinsing time in ion exchange water is critical for ionic layer formation. Thus, precipitation formation i.e. wastage of material, is avoided in SILAR method.

The successive ionic layer adsorption and reaction (SILAR) method is relatively a new and less investigated method, first reported in 1985 by Ristov et al. The name SILAR was ascribed to this method by Nicolau (1985) and discussed in subsequent papers of Nicolau and coworkers (Nicolau and Minnard 1988; Nicolau et al 1988), which deals with $\mathrm{ZnS}, \mathrm{CdZnS}$ and $\mathrm{CdS}$ thin films. The SILAR method is useful for the deposition of thin films of chalcogenide groups I-VI, II-VI, III-VI, V-VI, VIII-VI binary and I-III-VI, II-II-VI, II-III-VI, II-VI-VI and II-V-VI ternary chalcogenides and composite films.

\section{Concept of solubility and ionic product}

Sparingly soluble salt, $\mathrm{AB}$, when placed in water, a saturated solution containing $\mathrm{A}^{+}$and $\mathrm{B}^{-}$ions in contact with undissolved solid $\mathrm{AB}$ is obtained and an equilibrium is established between the solid phase and ions in the solution as

$$
\mathrm{AB}(S) \rightleftharpoons \mathrm{A}^{+}+\mathrm{B}^{-} \text {. }
$$

Applying the law of mass action,

$$
K=\left[C_{\mathrm{A}}^{+} \cdot C_{\mathrm{B}}^{-}\right] / C_{\mathrm{AB}},
$$

where $C_{\mathrm{A}}^{+}, C_{\mathrm{B}}^{-}$and $C_{\mathrm{AB}}$ are concentrations of $\mathrm{A}^{+}, \mathrm{B}^{-}$and $\mathrm{AB}$ in the solution, respectively. The concentration of pure solid is a constant number, i.e.

$$
\begin{aligned}
& C_{\mathrm{AB}}(S)=\text { constant }=K^{\prime}, \\
& K=\left[C_{\mathrm{A}}^{+} \cdot C_{\mathrm{B}}^{-}\right] / K^{\prime}, \\
& K K^{\prime}=C_{A}^{+} \cdot C_{\mathrm{B}}^{-} .
\end{aligned}
$$

Since $K$ and $K^{\prime}$ are constants, the product of $K K^{\prime}$ is also constant, say $K_{\mathrm{s}}$, therefore (5) becomes

$$
K_{\mathrm{s}}=C_{\mathrm{A}}^{+} \cdot C_{\mathrm{B}}^{-} \text {. }
$$

The constant, $K_{\mathrm{s}}$, is called solubility product (SP) and $\left(C_{\mathrm{A}}^{+} \cdot C_{\mathrm{B}}^{-}\right)$is called the ionic product (IP). When the solution is saturated, the ionic product is equal to the solubility product. But when the ionic product exceeds the solubility product, i.e.

$$
\mathrm{IP} / \mathrm{SP}=S>1,
$$

the solution is supersaturated ( $S=$ degree of supersaturation), precipitation occurs and ions combine on the substrate and in the solution to form nuclei. Temperature, solvent and particle size (Skoog and West 1963; Alexeyev 1971; Pietrzyk and Frank 1974; Lincot and Borges 1992) affect the solubility product. For any formation of thin film, there is some minimum number of ions or molecules, which produce a static phase in contact with solution, called nucleus. Nucleation on the substrate of surface starts at local homogeneity. The rate at which nuclei forms on the surface of the substrate, depends on the degree of supersaturation.

It is assumed that the formation of stable growth centres on the surface, $N(t)$, can be expressed as a function of total number of active sites on the surface, $N_{0}$, by the law

$$
N(t)=N_{0}[1-\exp (-A t)]
$$

where $A$ is nucleation rate constant. From these stable growth centres, various models have been proposed to describe either bidimensional (monolayer) or three-dimensional growth (Lokhande 1991).

Growth of particles, already present in the solution takes place in second step, when nuclei or other seed particles are present. In case of ionic solids, the process involves deposition of cation and anion on appropriate sites.

$$
\begin{aligned}
& (\mathrm{AB})_{n}+\mathrm{A}^{+}+\mathrm{B}^{-} \rightarrow(\mathrm{AB})_{n+1}, \\
& (\mathrm{AB})_{n+1}+\mathrm{A}^{+}+\mathrm{B}^{-} \rightarrow(\mathrm{AB})_{n+2},
\end{aligned}
$$

where $n$ is the minimum number of $\mathrm{A}^{+}$and $\mathrm{B}^{-}$required for giving stable phase, $(\mathrm{AB})_{n}$. The growth rate is directly proportional to the supersaturation

$$
\text { Rate of growth }=K_{0}{ }^{\prime} a(Q-S),
$$

where $a$ is surface area of the exposed solid and $K_{0}{ }^{\prime}$ the constant which is a characteristics of the particular precipitate. If the supersaturation is maintained at low level 
throughout the precipitation, relatively few nuclei are formed. That will grow to give a small number of large particles with high supersaturation, many more nuclei are formed initially and nucleation may occur through the precipitation process. As a result, there are great number of centres upon which growth process can take place, none of the particles grow very large and colloidal suspension is formed. The colloidal suspension consists of finely divided solid particles in a liquid phase with diameter about $0 \cdot 01-0 \cdot 1 \mathrm{~m}$. Under some circumstances, colloidal particles can come together and adhere to one another and the resulting solid is called colloidal precipitate and the process by which it is formed is called coagulation or agglomeration. Colloidal particles when agglomerated have quite different properties from a crystalline solid since the particles are arranged irregularly.

The growth kinetics of a thin film deposition process is of two types: (i) ion-by-ion growth where deposition process involves the ion-by-ion deposition at nucleation sites on the immersed surfaces and (ii) according to Lundin and Kitaev (1965), nucleation takes place by adsorption of the colloidal particles and growth takes place as a result of surface coagulation of these particles, giving thin and adherent film. This is known as cluster-by-cluster growth of the film.

\section{Theoretical background of SILAR}

The successive ionic layer adsorption and reaction (SILAR) method is mainly based on the adsorption and reaction of the ions from the solutions and rinsing between every immersion with deionized water to avoid homogeneous precipitation in the solution. The collection of a substance on the surface of another substance is known as adsorption, which is the fundamental building block of the SILAR method. The term adsorption can be defined as the interfacial layer between two phases of a system. Adsorption may be expected when two heterogeneous phases are brought into contact with each other. Hence, gas-solid, liquid-solid and gas-liquid are three possible adsorption systems. In SILAR method, we are only concerned with adsorption in liquid-solid system. Adsorption is an exothermic process. The adsorption is a surface phenomenon between ions and surface of substrate and is possible due to attraction force between ions in the solution and surface of the substrate. These forces may be cohesive forces or Van-der Waals forces or chemical attractive forces. Atoms or molecules of substrate surface are not surrounded by atoms or molecules of their kind on all sides. Therefore, they possess unbalanced or residual force and hold the substrate particles. Thus, adatoms can be holding on the surface of the substrate. The factors like temperature of solution, pressure, nature of the substrate, concentration of the solution, area of the substrate etc affect the adsorption process. The reaction in pre-adsorbed (cations) and newly adsorbed (anions) forms the thin films of desired material.

\subsection{Basic of SILAR}

The SILAR is based on sequential reaction at the substrate surface. Rinsing follows each reaction, which enables heterogeneous reaction between the solid phase and the solvated ions in the solution. The SILAR process is intended to grow thin films of water insoluble ionic or ion covalent compounds of the type $\mathrm{Kp} \mathrm{A} a$ by heterogeneous chemical reaction at the solid solution interface between adsorbed cations, $p \mathrm{~K}_{\mathrm{a}}^{+}$and anion, $a \mathrm{~A}_{\mathrm{p}}^{-}$, following the reaction

$$
\begin{aligned}
& \left(p \mathrm{~K}_{a q}^{a+}+q \mathrm{X}_{a q}^{b-}\right)+\left(b^{\prime} \mathrm{Y}_{a q}^{q^{\prime}+}+a \mathrm{~A}^{p-}\right) \rightarrow \\
& \mathrm{Kp} \mathrm{A} a_{\mathrm{S}} \downarrow+q \mathrm{X}_{a q}^{b-}+b^{\prime} \mathrm{Y}_{a q}^{q^{\prime}+} \\
& \text { with } a p=b q=b^{\prime} q^{\prime},
\end{aligned}
$$

where, $K$ represents cation $\left(\mathrm{Cd}^{2+}, \mathrm{Zn}^{2+}, \mathrm{Fe}^{3+}, \mathrm{Cu}^{+}\right.$, etc $), p$ represents the number of cations, $a$ represents the numerical value of charge on cation, $\mathrm{X}$ is a ion in cationic precursors having negative charge $\left(\mathrm{X}=\mathrm{SO}_{4}^{2-}, \mathrm{Cl}^{-}, \mathrm{NO}^{3-}\right.$ etc), $q$ represents the number of $\mathrm{X}$ in cationic precursors and $b$ the numerical value of charges on $\mathrm{X}, b^{\prime}$ the number of $\mathrm{Y}$ in the anionic solutions, $q^{\prime}$ the numerical value of charge on $\mathrm{Y}, \mathrm{Y}$ the ion which is attached to chalcogen ion, A represents the anion $(\mathrm{O}, \mathrm{S}, \mathrm{Se}$ and $\mathrm{Te}), a^{\prime}$ the number of anions. $\mathrm{A}$ is the chalcogen ion. In the presence of complexing agent, above reaction can be written as

$$
\begin{gathered}
\mathrm{P}\left[(\mathrm{KC})^{a+}\right]_{a q}+q \mathrm{X}_{a q}^{b-}+b^{\prime} \mathrm{Y}_{a q}^{q^{\prime}+}+a \mathrm{~A}^{p-} \rightarrow \\
\mathrm{K}^{\prime} \mathrm{A} a_{\mathrm{S}}^{\prime} \downarrow+\mathrm{C}+q \mathrm{X}_{a q}^{b-}+b^{\prime} \mathrm{Y}_{a q}^{q^{\prime}+},
\end{gathered}
$$

where $\mathrm{C}$ is complexing agent. Figure 1 represents the basis of SILAR growth. It consists of atleast four different steps: adsorption, rinsing (I), reaction and rinsing (II).

Adsorption: In this first step of SILAR process, the cations present in the precursor solution are adsorbed on the surface of the substrate and form the Helmholtz electric double layer. This layer is composed of two layers: the inner (positively charged) and outer (negatively charged) layers. The positive layer consists of the cations and the negative form the counter ions of the cations.

Rinsing (I): In this step, excess adsorbed ions, $p \mathrm{~K}^{a+}$ and $a \mathrm{~A}^{p-}$, are rinsed away from the diffusion layer. This results into saturated electrical double layer.

Reaction: In this reaction step, the anions from anionic precursor solution are introduced to the system. Due to the low stability of the material, $\mathrm{Kp} \mathrm{A} a$, a solid substance is formed on the interface. This process involves the reaction of $p \mathrm{~K}^{a+}$ surface species with the anionic precursor, $a \mathrm{~A}^{p-}$. 
Rinsing (II): In last step of a SILAR cycle, the excess and unreacted species $a \mathrm{~A}^{p-}, \mathrm{X}, \mathrm{Y}$, and the reaction byproduct from the diffusion layer are removed.

By repeating these cycles, a thin layer of material, $\mathrm{K} p \mathrm{~A} a$, can be grown. Following the above-mentioned steps the maximum increase in film thickness per one reaction cycle is theoretically one monolayer. This results into a solid layer of the compound $\mathrm{Kp} \mathrm{A} a$. Dividing the measured overall film thickness by number of reaction cycles, growth rate can be determined. This gives a numerical value for growth rate under the given conditions. If the measured growth rate exceeds the lattice constant of the material, a homogeneous precipitation in the solution could have taken place. In practice, however, the thickness increase is typically less than or greater than a monolayer. Thus, the process involves an alternate immersion of the substrate in a solution containing a soluble salt of the cation of the compound to be grown. The substrate supporting the growing film is rinsed in highly purified deionized water after each immersion.

The facts affecting the growth phenomena are the quality of the precursor solutions, their $\mathrm{pH}$ values, concentrations, counter ions, individual rinsing and dipping times. In addition, complexing agent and pretreatment of the substrate have been shown to affect the SILAR growth.

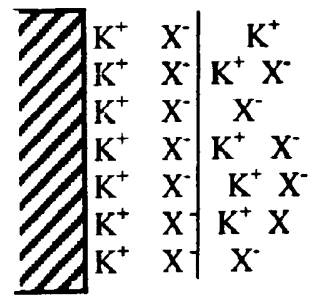

(a)

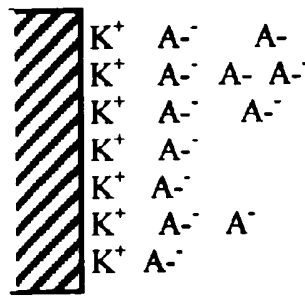

(c)

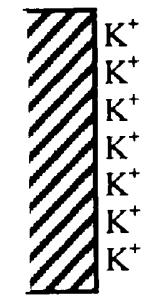

(b)

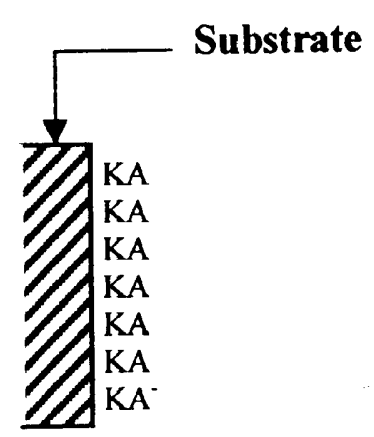

(d)
Figure 1. Schematic diagram of SILAR growth: (a) Adsorption of $\mathrm{K}^{+} \mathrm{X}^{-}$and the formation of electrical double layer, (b) rinsing (I) removes excess, unabsorbed $\mathrm{K}^{+}$and $\mathrm{X}^{-}$, (c) reaction of $\mathrm{A}^{-}$with pre-adsorbed $\mathrm{K}^{+}$ions to form $\mathrm{KA}$ and (d) rinsing (II) to remove excess and unreacted species and form the solid solution KA on surface of the substrate.

\subsection{Mechanism of SILAR method}

The growth mechanism involves three most important steps: (i) specific adsorption of the most strongly adsorbed ions of the compound to be grown, by the substrate immersion in a solution of one of its cationic precursor, (ii) water rinsing of the excess solution still adhering to the substrate, and (iii) chemical reaction between the most strongly specific adsorbed cations and the less strongly adsorbed anions by the subsequent substrate immersion in the solution.

In the following, in view of a better understanding but without limiting the generality of the process, we shall discuss the growth mechanism taking as an example the growth of CdS thin films. Solution of $\mathrm{CdSO}_{4}$ and $\mathrm{Na}_{2} \mathrm{~S}$ are used as immersion baths. Figure 2 shows experimental set-up of manually operated SILAR deposition system. It mainly consists of beakers of cationic precursor $\left(\mathrm{CdSO}_{4}\right)$, anionic precursor $\left(\mathrm{Na}_{2} \mathrm{~S}\right)$ and highly purified water. For the deposition of binary chalcogenide (CdS) thin film, atleast four beakers are needed. The beakers of precursor and beaker of rinsing are alternately placed, each rinsing beaker being placed between a beaker containing a solution of a salt of the cation and another containing a solution of salt of the anion. For the deposition of CdS thin films, a well cleaned glass substrate is immersed in cationic precursor solution of $\mathrm{CdSO}_{4}$ (figure $2 \mathrm{a}$ ) in which $\mathrm{Cd}^{2+}$ and $\mathrm{SO}_{4}^{2-}$ ions are adsorbed on the surface of the substrate $\left(\mathrm{CdOH}^{+}\right.$adsorption is neglected). The substrate is rinsed in ion exchange water (figure $2 \mathrm{~b}$ ) to remove unadsorbed $\mathrm{Cd}^{2+}$ and $\mathrm{SO}_{4}^{2-}$ ions. In order to avoid the homogeneous precipitation in the diffusion layer at the next immersion in the $\mathrm{Na}_{2} \mathrm{~S}$ solution, the rinsing time must be experimentally determined or calculated so that the residual activity of the $\mathrm{Cd}^{2+}$ in the diffusion layer $\left[\mathrm{Cd}_{\mathrm{r}}^{2+}\right]$ should be $\left[\mathrm{Cd}_{\mathrm{r}}^{2+}\right]<\mathrm{K}_{\mathrm{so}}\left[\mathrm{H}^{+}\right] / \mathrm{K}\left[\mathrm{HS}^{-}\right]$. Here $K_{\mathrm{so}} \cong 10^{-28}$ is the solubility product of $\mathrm{CdS}$. The substrate is then immersed in an anionic precursor (figure 2c) solution. During the next immersion in the $\mathrm{Na}_{2} \mathrm{~S}$ solution, the $\mathrm{HS}^{-}, \mathrm{S}^{2-}, \mathrm{OH}^{-}$ and $\mathrm{Na}^{+}$ions diffuse from the solution in the diffusion layer towards solid solution interface until their concentration in the diffusion equals those in bath. The immersion time is experimentally calculated. The $\mathrm{HS}^{-}$and $\mathrm{S}^{2-}$ enter the outer Helmoltz layer, react with the adsorbed $\mathrm{Cd}^{2+}$ and form CdS monolayer. This is followed by rinsing again in ion exchange water (figure $2 \mathrm{~d}$ ) to remove $\mathrm{Cd}^{2+}, \mathrm{S}^{2-}$ ions, unreacted and loosely bounded CdS material and other byproducts. This completes one deposition cycle for the deposition of CdS film. By repeating such deposition cycles, continuous $\mathrm{CdS}$ films on the substrate surface is possible. The overall reaction can be written as

$$
\begin{aligned}
& \mathrm{Cd}_{a q}^{2+}+\mathrm{SO}_{4}^{2-}{ }_{a q}+2 \mathrm{Na}^{+}{ }_{a q}+\mathrm{S}_{a q}^{2-} \rightarrow \mathrm{CdS} \downarrow+ \\
& 2 \mathrm{Na}_{a q}^{+}+\mathrm{SO}_{4}^{2-}{ }_{a q} .
\end{aligned}
$$




\section{SILAR deposition systems}

The critical operations for the deposition of thin films by successive ionic layer adsorption and reaction (SILAR) method, are adsorption of the cations, rinsing with deionized water, reaction of pre-adsorbed cations with newly adsorbed anions and again rinsing with deionized water. Generally, manual, electropneumatic and computer based systems have been used to perform these operations in SILAR method. These methods are discussed in brief in the following sections.

\subsection{Manually operated}

This system does not require any power supply for operations, hence it is economical. In this system, four or more glass beakers of typically $50 \mathrm{ml}$ capacity containing precursor solutions and deionized water are placed separately in the tray. The beakers containing precursor solutions and deionized water are alternately placed as shown in figure 2 . The beaker containing deionized water is placed in between the beakers containing cationic and anionic precursor solutions. The immersion and rinsing of substrates are done manually. The SILAR deposition of sufficiently thick film requires many hours and therefore manual deposition of certain materials is not possible for a single person.

\subsection{Computer based}

The schematic diagram of computer-based operating system (Nicolau 1985; Jim'enez-Gonz'ailez and Nair 1995) is shown in figure 3. The equipment consists of two beakers of $50 \mathrm{ml}$ each containing the precursor solution and two rinsing vessels, lying in a circle on the circular tray. Each rinsing vessel being placed in between beakers containing cationic and anionic precursor solutions. The substrates are attached vertically by means of four arms. The arms are set out in line or a right angle and supported on the spindle. The spindle can turn and slide tightly in a bearing. Two steeping motors drive it. The computer program governs the vertical and translation movement of the spindle.

\subsection{Microprocessor based}

The schematic diagram of microprocessor-based operating system is shown in figure 4 . The equipment is feasible for elemental, binary, ternary, composite etc materials.

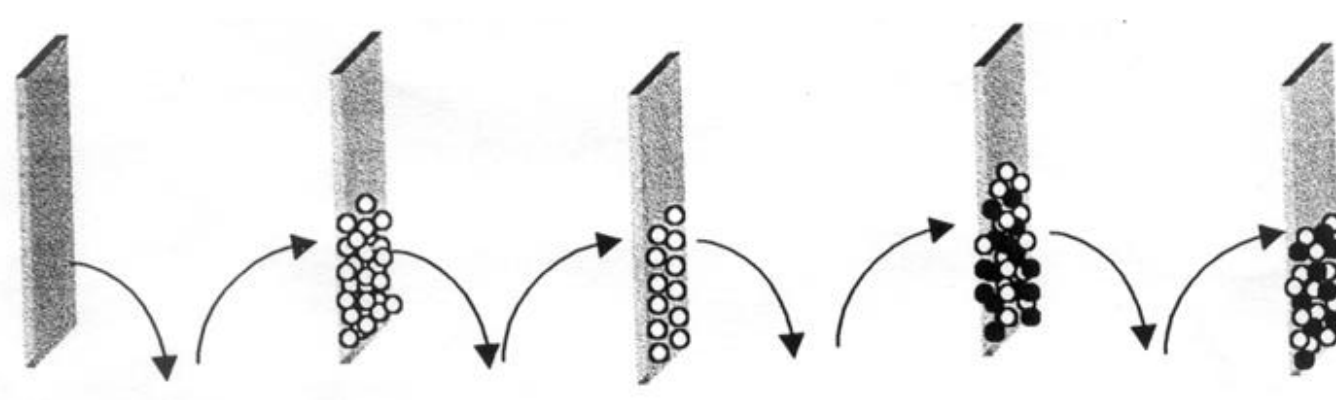

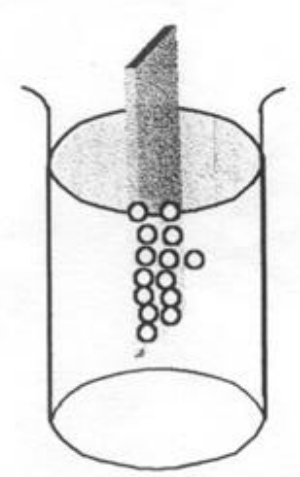

(a)

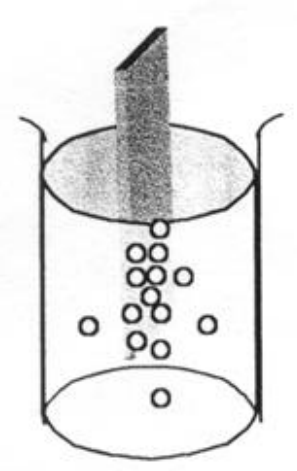

(b)

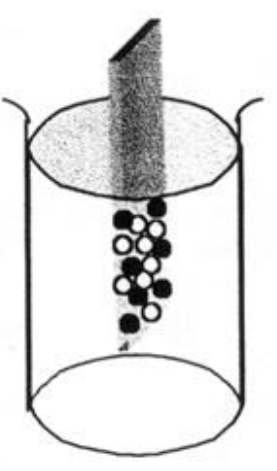

(c)

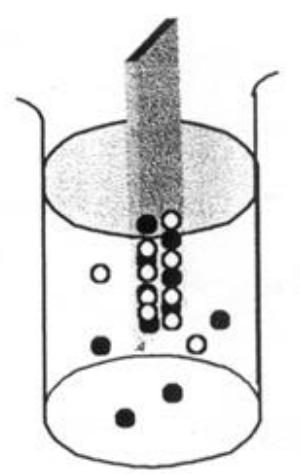

(d)

Figure 2. The scheme of SILAR method for the deposition of CdS thin films $\left(\mathrm{O}, \mathrm{Cd}^{2+} ; \bullet \bullet, \mathrm{S}^{2-}\right)$ : (a) $\rightarrow$ cationic precursor, $(\mathbf{b}) \rightarrow$ ion exchange water, $(\mathbf{c}) \rightarrow$ anionic precursor and $(\mathbf{d}) \rightarrow$ ion exchange water. 
Each rinsing vessel being placed in between beakers containing cationic and anionic precursor solutions. The substrates are attached vertically by means of robotic arms. The microprocessor governs the vertical and translational movement of the robotic arms.

\section{Metal chalcogenide films by SILAR method}

Metal chalcogenide thin films prepared by SILAR method are of particular interest as in recent years, thin film technology has developed enormously due to the fact that one dimension of film is negligible and that is relatively easy to produce by SILAR method. The technology of thin films deals with the films of thickness between

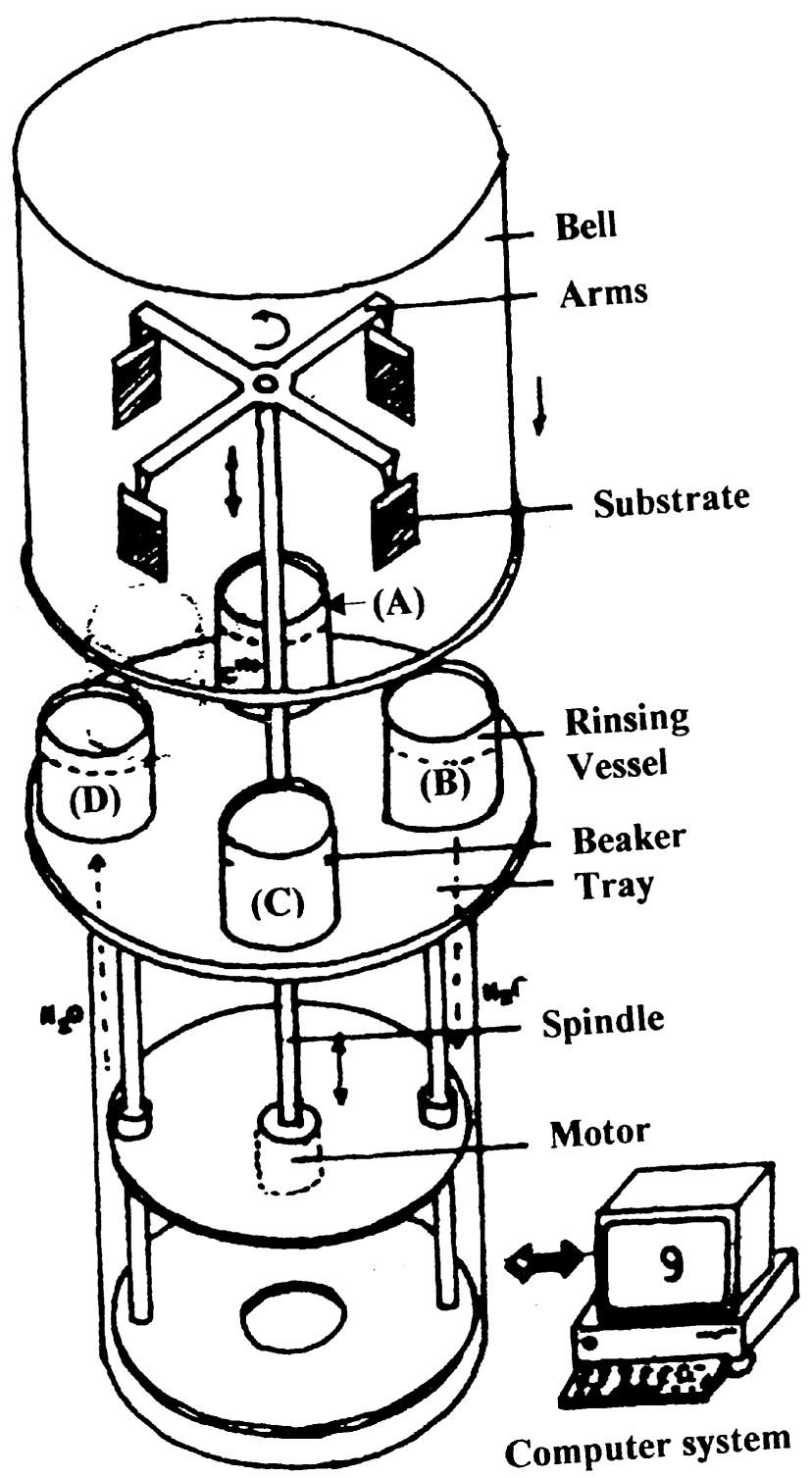

Figure 3. Computer based SILAR deposition system: (a) $\rightarrow$ cationic precursor, (b) $\rightarrow$ ion exchange water, (c) $\rightarrow$ anionic precursor and $(\mathbf{d}) \rightarrow$ ion exchange water. tenths of nanometers and several micrometers can be easily prepared by SILAR. The SILAR plays a pivotal role in the deposition of materials. This method is suitable for industrial application to develop synthetic materials of tailored properties for communication, information and solar energy conversion with decreased size of active electronic components, a higher packing density, higher seed performance and lower cost.

\subsection{Metal sulphide thin films}

5.1a Copper sulphide: Copper sulphide belongs to I-VI compound semiconductor material. At room temperature, copper sulphide $(\mathrm{CuS})$ forms five stable phases: covellite $(\mathrm{CuS})$, anilite $\left(\mathrm{Cu}_{1.7} \mathrm{~S}\right)$, digenite $\left(\mathrm{Cu}_{1.8} \mathrm{~S}\right)$, djurteite $\left(\mathrm{Cu}_{1.95} \mathrm{~S}\right)$ and chalcocite $\left(\mathrm{Cu}_{2} \mathrm{~S}\right)$. Copper sulphide has different crystal structures depending upon the value of $\mathrm{X}$ such as hexagonal, orthorhombic, pseudo cubic and tetragonal. $\mathrm{Cu}_{x} \mathrm{~S}$ has hexagonal crystal structure and $\mathrm{Cu}_{2} \mathrm{~S}$ may be present in both the crystal structures viz. orthorhombic and hexagonal. Generally the films are blue-black in colour. The optical band gap of $\mathrm{Cu}_{x} \mathrm{~S}$ varies in the region of 1.2 $2.5 \mathrm{eV}$. The variation in electrical conductivity is from $0.07 \Omega^{-1} \mathrm{~cm}$ to $2400 \Omega^{-1} \mathrm{~cm}$ as $x$ varied from 2 to $1 \cdot 8$. It is a $p$-type semiconducting material. Copper sulphide thin films have received particular attention since the discovery of the $\mathrm{CdS} / \mathrm{Cu}_{x} \mathrm{~S}$ heterojunction solar cell in 1954. $\mathrm{Cu}_{x} \mathrm{~S}$ thin films have been found to possess near ideal solar control characteristics: transmittance in the infrared region, low reflectance $<10 \%$ in the visible region so as to avoid glare and relatively high reflectance $>15 \%$ in the near infrared region. The films can also be used in laminated glazing. $\mathrm{Cu}_{x} \mathrm{~S}$ thin films have an interesting range of applications as photothermal conversion, electrocon-

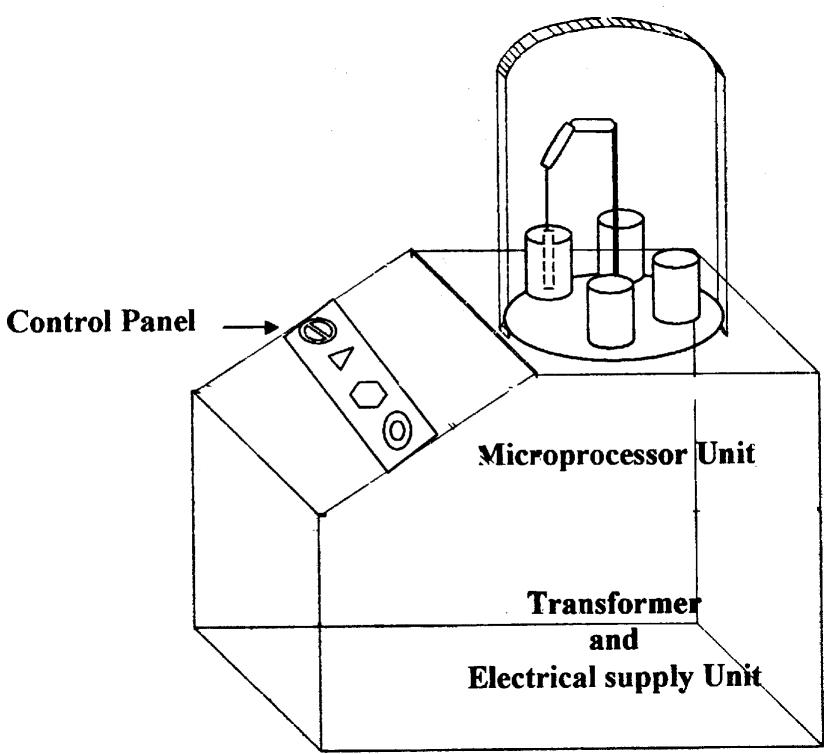

Figure 4. Microprocessor based SILAR deposition system. 

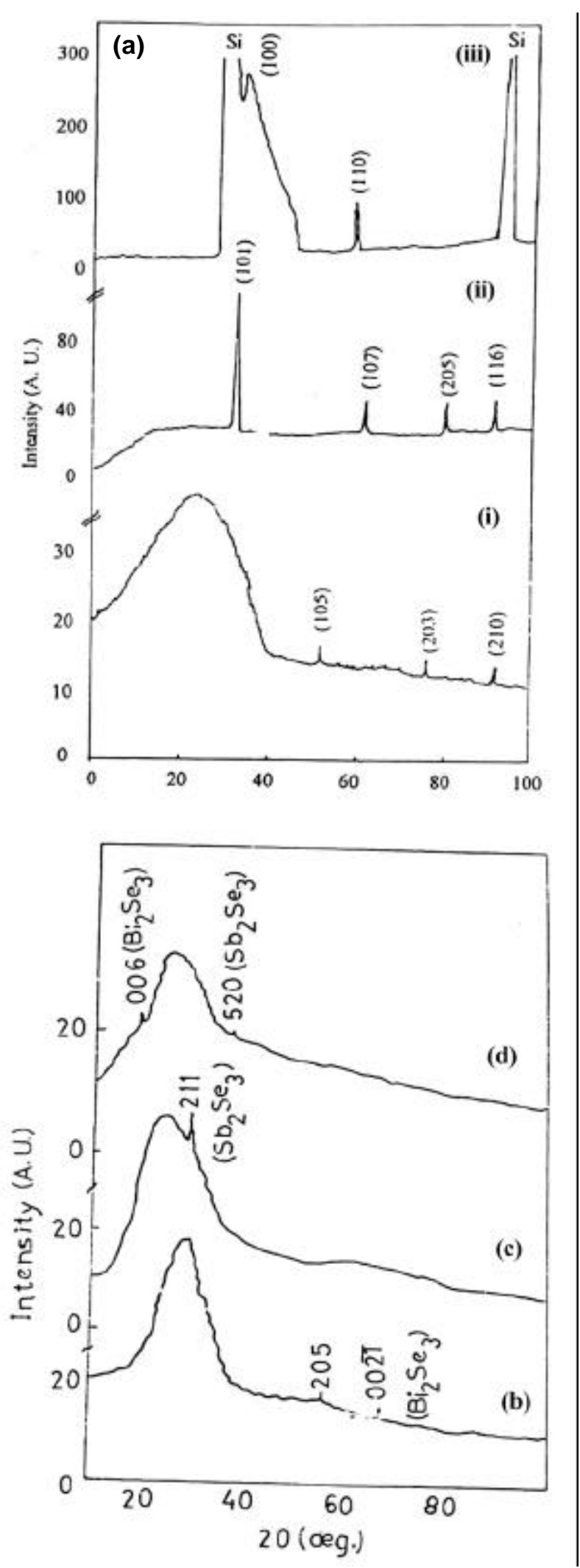

Figure 5. Typical X-ray diffraction patterns of SILAR deposited (a) $\mathrm{MoS}_{2}$ thin films onto various substrates (i) amorphous glass, (ii) FTO coated glass and (iii) $\mathrm{Si}$ (111) wafer, (b) $\mathrm{Bi}_{2} \mathrm{Se}_{3}$, (c) $\mathrm{Sb}_{2} \mathrm{Se}_{3}$, and (d) $\mathrm{Bi}_{2} \mathrm{Se}_{3}-\mathrm{Sb}_{2} \mathrm{Se}_{3}$ thin films. ductive electrode, microwave shielding and solar control coatings (Grozdanov and Najdoski 1995; Suarez and Nair 1996; Nascu et al 1997). It is also used in photo-detectors and in photovoltaic applications. The deposition of $\mathrm{Cu}_{x} \mathrm{~S}$ thin films, using SILAR method has been investigated by many workers (Lindroos et al 2000; Sartale and Lokhande 2000a; Pathan and Lokhande 2001a). Scanning electron micrograph of copper sulphide is shown in figure 6(e). The films are dense, smooth and homogeneous without visible pores. Figure $8(\mathrm{c})$ shows high-resolution transmission electron micrograph (HRTEM) of $\mathrm{Cu}_{2} \mathrm{~S}$ film. It shows that the film is composed of grains with diameter of about $8 \mathrm{~nm}$, which confirms the nanocrystalline nature of $\mathrm{Cu}_{2} \mathrm{~S}$ films.

5.1b Silver sulphide: Silver sulphide belongs to I-VI compound semiconductor materials. It has monoclinic crystal structure. The optical band gap of $\mathrm{Ag}_{2} \mathrm{~S}$ is around $1 \cdot 1 \mathrm{eV}$. The films are blackish. The electrical resistivity of the film was found to be of the order of $10^{4} \Omega \mathrm{cm}$. The $\mathrm{Ag}_{2} \mathrm{~S}$ shows $n$-type electrical conductivity. Thin films of $\mathrm{Ag}_{2} \mathrm{~S}$ have applications in photoconducting cells, IR detectors, solar selective coating, photovoltaic cell and photochemical cells.lb In the visible region and near IR region, $\mathrm{Ag}_{2} \mathrm{~S}$ barrier layer is used as detectors. Recently, the use of $\mathrm{Ag}_{2} \mathrm{~S}$ in the photoelectrochemical storage cells as a storage electrode has created much interest as the current efficiency of $\mathrm{Ag} / \mathrm{Ag}_{2} \mathrm{~S}$ couple is about $90 \%$ (Hodes et al 1976; Lokhande and Pawar 1982). Sankapal et al (2001) reported the deposited $\mathrm{Ag}_{2} \mathrm{~S}$ thin films and photoelectrochemical (PEC) study was carried out by Pathan et al (2001a).

5.1c Zinc sulphide: Zinc sulphide belongs to II-VI compound semiconductor materials. $\mathrm{ZnS}$ thin films may be present in cubic or/and hexagonal crystal structure. Generally, the chemically deposited films are of mixed phases of cubic and hexagonal crystal structure. The optical band gap of $\mathrm{ZnS}$ thin films lies in between 3.6 to $4 \mathrm{eV}$. The electrical resistivity is of the order of $10^{4} \Omega \cdot \mathrm{cm}$ with $n$ type electrical conductivity. Zinc sulphide is an important semiconductor material with a large optical band gap $(>3.5 \mathrm{eV})$, which has vast potential use in thin film devices, such as photoluminescent and electroluminescent devices. Besides, $\mathrm{ZnS}$ could be an important material in short wavelength emitting diode. Fabrication of graded bandgap $\mathrm{Cu}(\mathrm{In}, \mathrm{Ga}) \mathrm{Se}_{2}$ thin film mini-modules with a ( $\mathrm{Zn}$, $\mathrm{O}, \mathrm{S}, \mathrm{OH}$ ) buffer layer has been reported (Sushiya et al 1996). Many workers (Nicolau and Minnard 1988; Lindroos et al 1997, 1998; Lokhande et al 2002) investigated the deposition of $\mathrm{ZnS}$. Manganese doped zinc sulphide $(\mathrm{ZnS}: \mathrm{Mn})$ thin films have been seen from their use in electroluminescent display. The deposition of $\mathrm{ZnS}: \mathrm{Mn}$ thin film was carried out by Lindroos et al (1995). Figure 8 shows the high-resolution transmission electron micrograph (HRTEM) of $\mathrm{Zn}_{x}(\mathrm{O}, \mathrm{H})_{y}$ thin film. By HRTEM, random orientation of nanoparticles can be clearly seen. Small nanoparticles with dimensions $(50-60 \mathrm{~nm})$ are identified. 
5.1d Cadmium sulphide: Cadmium sulphide belongs to II-VI compound semiconductor materials. Cadmium sulphide exists as a mixed phase (wuztite and zinc-blend). The optical band gap energy varies from $2 \cdot 17$ to $2 \cdot 24 \mathrm{eV}$. The electrical resistivity of the $\mathrm{CdS}$ is of the order of $10^{5} \Omega \cdot \mathrm{cm}$ with $n$-type electrical conductivity and is often used in optoelectronic devices. Especially, in case of chalcopyrite heterojunction solar cells, it acts as a buffer layer. In the conventional absorber-window configuration of thin film heterojunction solar cells, $n$-CdS window have paired with $p-\mathrm{Cu}_{2} \mathrm{~S}, p$-CdTe and $p$-CuInSe $\mathrm{Sabsor}_{2}$ abser layers to result in efficient solar cells. Also, cadmium sulphide is a promising semiconducting material in the conversion of solar energy into electrical energy by means of PEC process. Cadmium sulphide (CdS) has been employed in high efficiency solar cells formed with $\mathrm{Cu}_{2} \mathrm{~S}$ (Hall and Meakin 1979), $\mathrm{Cu}(\mathrm{In}, \mathrm{Ga}) \mathrm{Se}_{2}$ (Dimmler and Schock 1996) and CdTe (Britt and Ferekides 1993). The CdS are also used as photoconductors, photo-resistors, and transistor image magnification and recently in light activated valves for large screen liquid crystal display. Many workers (Nicolau 1985; Nicolau and Minnard
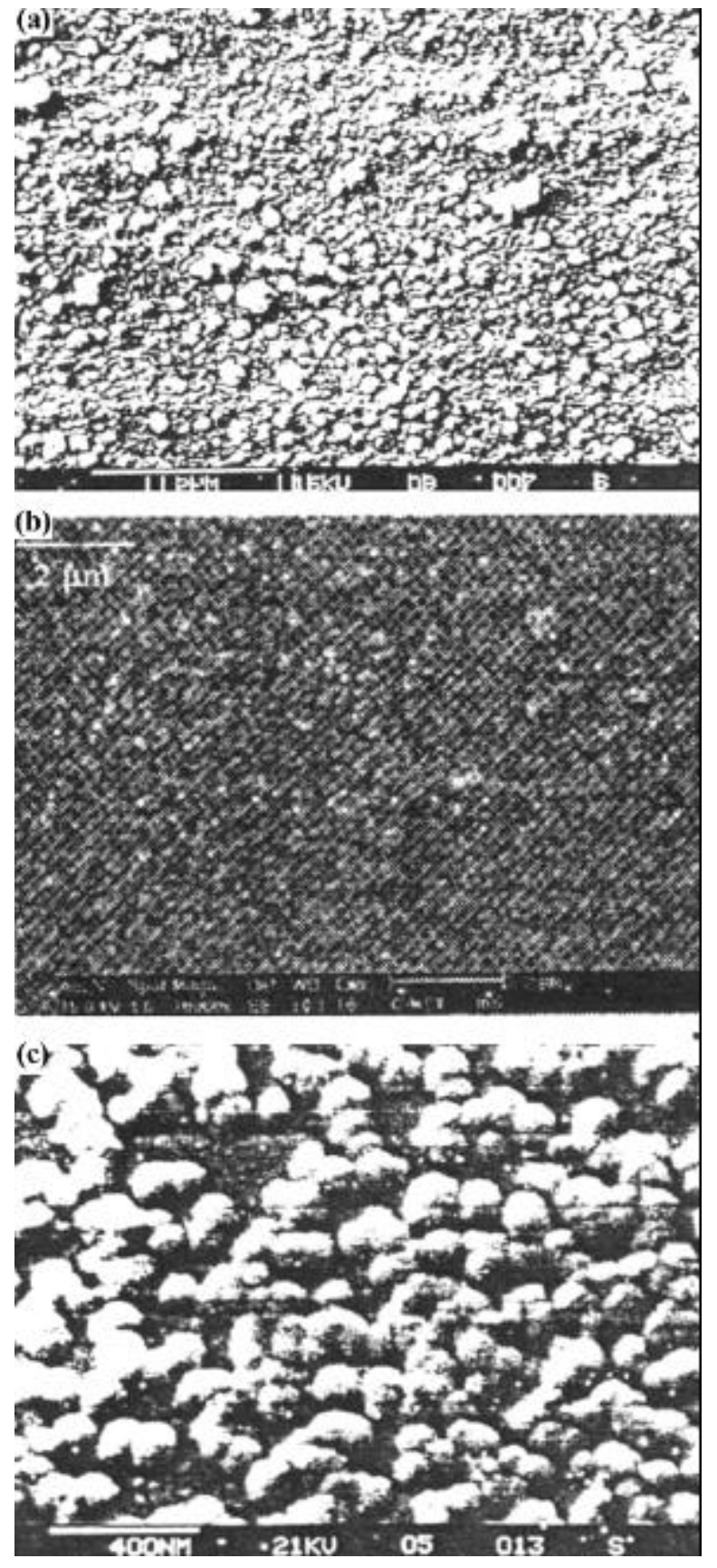
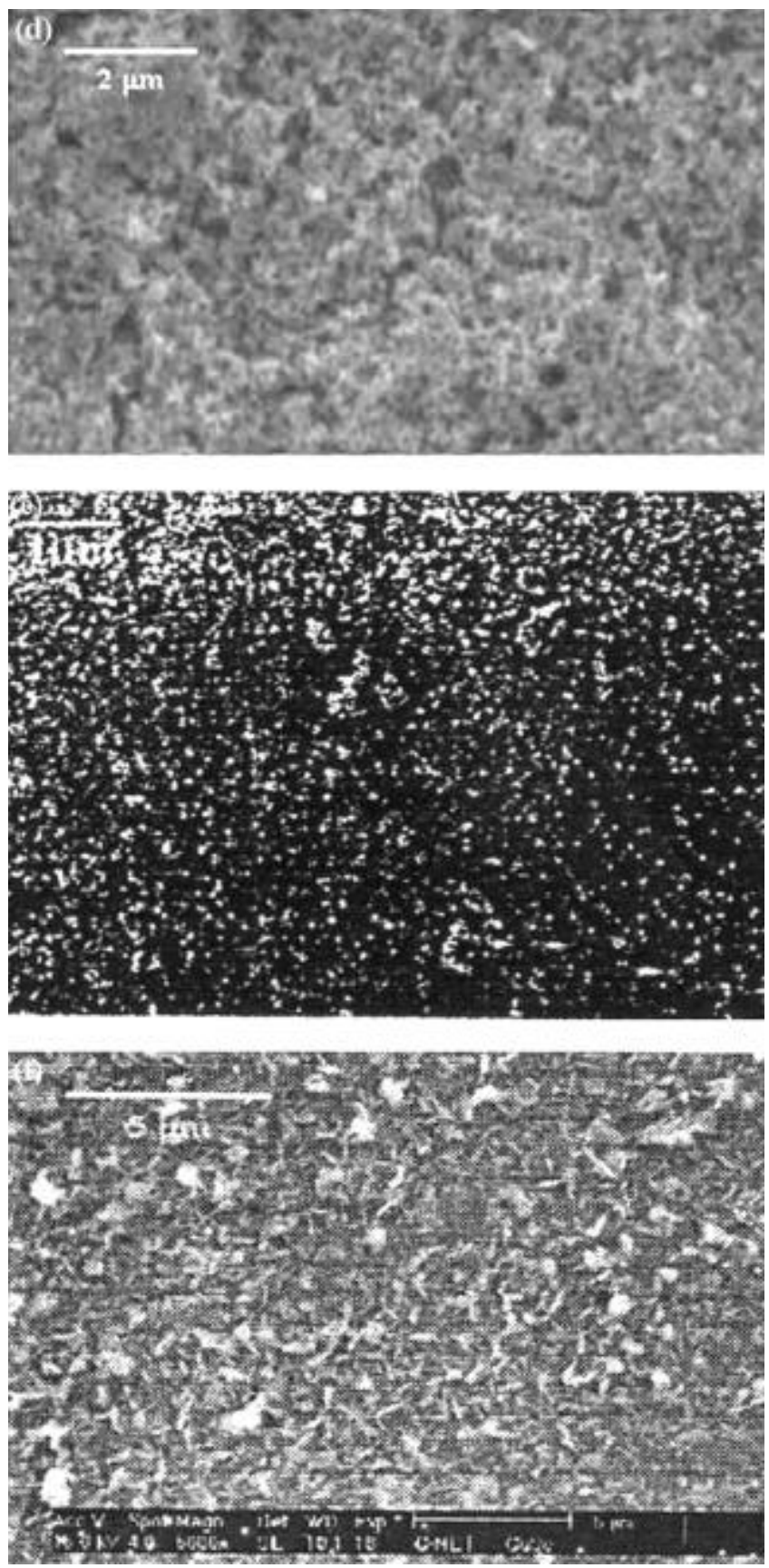

Figure 6. Typical SEMs of SILAR deposited (a) CdS, (b) InS, (c) $\mathrm{Bi}_{2} \mathrm{~S}_{3}$, (d) InTe, (e) CuS and (f) CuSe thin films. 
1988; Nicolau et al 1988; Valkonen et al 1997a,b; Sankapal et al 2000b; Lokhande et al 2001) have carried out the deposition of CdS. Scanning electron micrograph of CdS is shown in figure 6(a). The films are dense, smooth and homogeneous without visible pores. Figure 8(a) shows the high-resolution transmission electron micrograph (HRTEM) of CdS thin film. By HRTEM, random orientation of nanoparticles can be clearly seen. Plots of optical absorption against wavelength (inset) and $(\alpha h v)^{2}$ against $h v$ for SILAR deposited CdS thin film are shown in figure 9. Figure 10 shows the plot of $\log \rho$ against $(1000 / T) \mathrm{CdS}$ thin film. The room temperature electrical resistivity was found to be of the order of $10^{6} \Omega \cdot \mathrm{cm}$.

Manganese doped cadmium sulphide ( $\mathrm{CdS}: \mathrm{Mn})$ thin films are the potential candidates in thin film photovoltaic devices as window/buffer material. The basic requirement of buffer layer such as high resistivity, high band gap etc may be satisfied by $\mathrm{CdS}: \mathrm{Mn}$. The films of CdS : Mn was deposited by Kulkarni et al (2002).

5.1e Indium sulphide: Indium sulphide belongs to III-VI compound semiconductor materials. The InS has orthorhombic, $\operatorname{In}_{2} \mathrm{~S}_{3}$ has tetragonal and $\operatorname{In}_{6} \mathrm{~S}_{7}$ has monoclinic crystal structure. The band gap increases from $2 \cdot 1 \mathrm{eV}$ for pure $\mathrm{In}_{2} \mathrm{~S}_{3}$ to 2.6 to $2.9 \mathrm{eV}$ in the presence of oxygen. The films are dark greyish-red. The electrical resistivity is around the $10^{7}-10^{9} \Omega \mathrm{cm}$ with $n$-type electrical conductivity. Depending upon temperature and pressure, it exists in different modifications $(\alpha, \beta$ and $\gamma)$. Its band gap varies between 2.0 and $2.9 \mathrm{eV}$, depending upon the composition and crystal size. The $\mathrm{Cu}(\mathrm{In}, \mathrm{Ga}) \mathrm{Se}_{2}$ based solar cell prepared with the chemically deposited $\operatorname{In}_{2} \mathrm{~S}_{3}$ as a buffer layer reached the efficiency $(15.7 \%)$ near to those obtained by device made with standard CdS buffer layer. The deposition of $\mathrm{In}_{2} \mathrm{~S}_{3}$ by SILAR method is investigated by our group using $\mathrm{InCl}_{3}$ and $\mathrm{In}_{2}\left(\mathrm{SO}_{4}\right)_{3}$ as a In source (Lokhande and Pathan 2000b; Pathan et al 2001b). Scanning electron micrograph of indium sulphide is shown in figure 6. The films are dense, smooth and homogeneous. Plot of $\log \rho$ against $(1000 / T)$ for SILAR deposited indium sulphide thin film is shown in figure 10 . The room temperature electrical resistivity is found to be of the order of $10^{6} \Omega \mathrm{cm}$.

5.1f Tin sulphide: Tin sulphide ( $\mathrm{SnS}$ ) belongs to IV-VI compound semiconductor materials. Tin sulphide appears to be in different phases as $\mathrm{SnS}, \mathrm{SnS}_{2}$ etc. The films are of brown colour. It has a band gap of 1.3 to $1.5 \mathrm{eV}$. The electrical resistivity is of the order of $10^{4}-10^{5} \Omega \mathrm{cm}$ with $p$-type electrical conductivity. The high conversion efficiency, $\sim 25 \%$, is obtainable in photovoltaic devices according to Prince-Loferski diagram and its acceptability from the point of view of cost, availability, toxicity and stability ascribe to $\mathrm{SnS}$ a unique position among the metal sulphides, probably to be shared only by $\mathrm{FeS}_{2}$.
Tin disulphide $\left(\mathrm{SnS}_{2}\right)$ has hexagonal crystal structure. Tin disulphide is a layer compound with $\mathrm{CdI}_{2}$ type structure, it is composed of a sheet of tin atoms sandwiched between two close packed sheets of sulphur atoms. The optical band gap energy is of the order of $2.6 \mathrm{eV}$. The electrical resistivity is of the order of $10^{3} \Omega \mathrm{cm}$ with $n$ type electrical conductivity. Tin disulphide shows electrical and optical properties that are useful in many devices, such as current controlled devices, switching devices, and photoconducting cells (Patil and Fredgold 1971; Said and Lee 1973). The deposition of tin disulphide was carried out using SILAR method by Sankapal et al (2000c).

5.1g Lead sulphide: Lead sulphide belongs to IV-VI compound semiconductor materials. The colour of the film is greyish-black. Lead sulphide $(\mathrm{PbS})$ has direct band gap of $0.4-0.78 \mathrm{eV}$. The electrical resistivity of the film is of the order of $10^{5}-10^{6} \Omega \mathrm{cm}$. Its absorption coefficient continuously increases from the infrared $\left(150 \mathrm{~cm}^{-1}\right.$ at $\left.3 \mu \mathrm{m}\right)$ through the visible region and has been used in infrared detectors since mid 1940s. The lead sulphide $(\mathrm{PbS})$ is used in infrared sensors (Moss 1955; Slater 1956). In solar energy research, $\mathrm{PbS}$ thin films were investigated for photothermal conversion application either independently on metallic substrates (Gupta et al 1979; Agnihotri and Gupta 1981) or in stacked multilayer (Reddy et al 1981, 1987). The PbS films were deposited by Kanniainen et al (2000) and Resch et al (1997).

5.1h Arsenic sulphide: Arsenic sulphide belongs to V-VI compound semiconductor materials. It has monoclinic crystal structure. The optical bad gap energy is $2.38 \mathrm{eV}$. The electrical resistivity varies from $10^{4}-10^{5} \Omega \mathrm{cm}$ with $n$-type electrical conductivity. Arsenic sulphide $\left(\mathrm{As}_{2} \mathrm{~S}_{3}\right)$ is a technically important class of material because of its good transparency in the $0 \cdot 7-11 \mu \mathrm{m}$ wavelength range and excellent resistance against moisture and corrosion. It is well known that $\mathrm{As}_{2} \mathrm{~S}_{3}$ has a variety of applications in optical imaging, hologram recording, various electronic devices including electro-optic information storage devices and optical mass memories (Rawson 1967; Maruno et al 1971; Tanaka 1975; Tanaka and Ohtsuka 1979; Danko et al 1991). The deposition of arsenic sulphide was carried out by Sartale and Lokhande (2000b).

5.1i Antimony sulphide: Antimony trisulphide belongs to V-VI group materials. It has orthorhombic crystal structure. The density of $\mathrm{Sb}_{2} \mathrm{~S}_{3}$ is $4.12 \mathrm{~g} / \mathrm{cm}^{3}$. The optical band gap of $\mathrm{Sb}_{2} \mathrm{~S}_{3}$ is $1.8 \mathrm{eV}$. The electrical resistivity is around $10^{4} \Omega \mathrm{cm}$ with $n$-type electrical conductivity. It finds some special application in the target material for television cameras, microwave devices, switching devices and various optoelectronic devices. It is also an important material in view of its photosensitive and thermoelectric properties. It has applications in paint and polymer industries, microwave devices, switching devices and various 
optoelectronic devices (Desai and Lokhande 1994). The $\mathrm{Sb}_{2} \mathrm{~S}_{3}$ films were deposited by Sankapal et al (1999a). Figure 7 shows the 2D and 3D AFMs of $\mathrm{Sb}_{2} \mathrm{~S}_{3}$ film. The film appears to be made up of fine particles or nanoparticles. 5.1j Bismuth sulphide: Bismuth sulphide belongs to $\mathrm{V}-\mathrm{VI}$ compound semiconductor materials. Its occurring naturally in grey crystalline form is referred to as 'bismuth glance' or bismuthinite. Both natural and artificial crys-

(a)

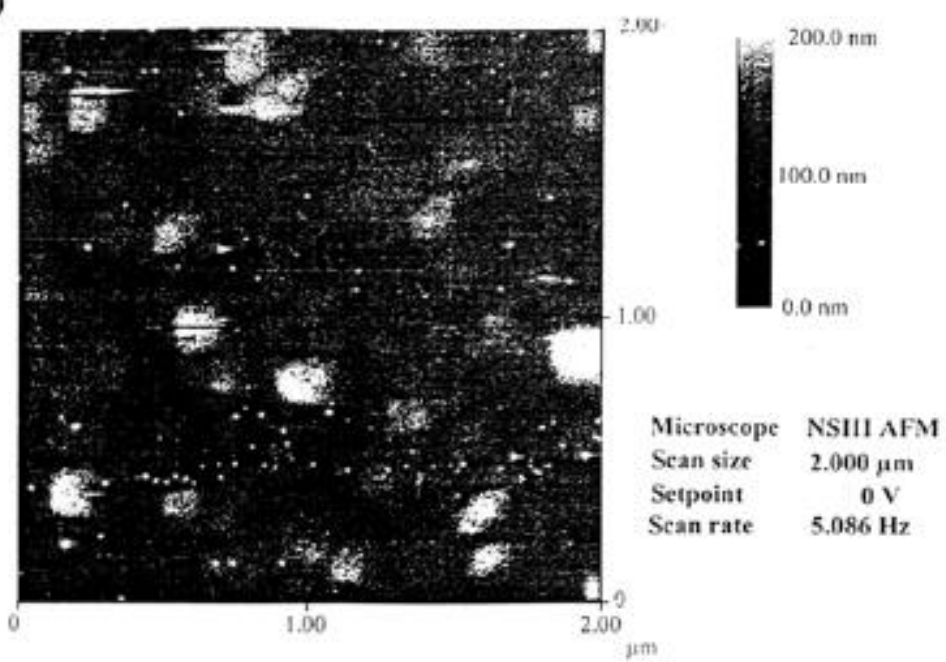

(b)
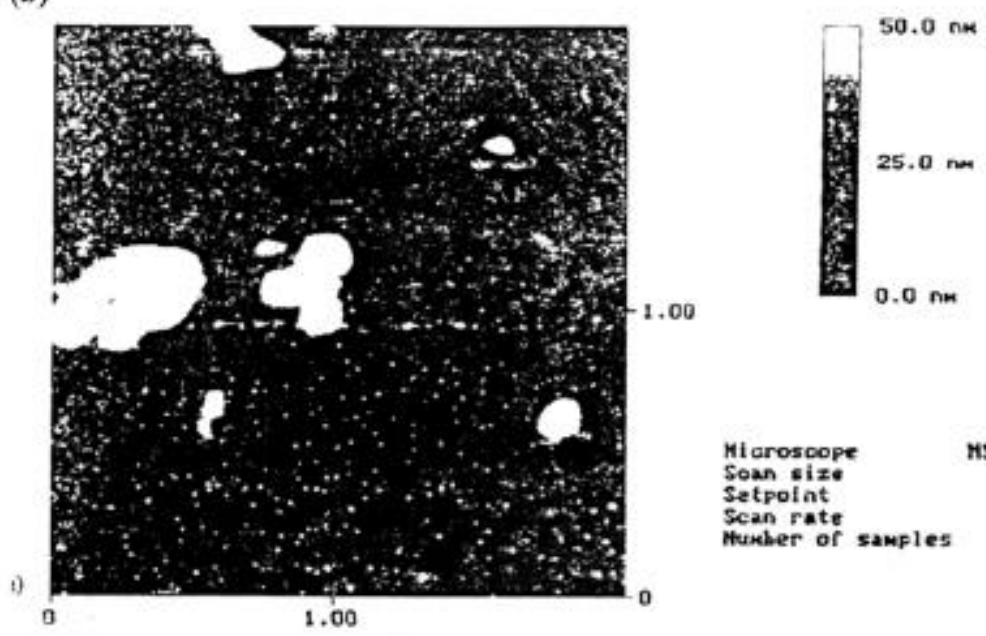

(c)
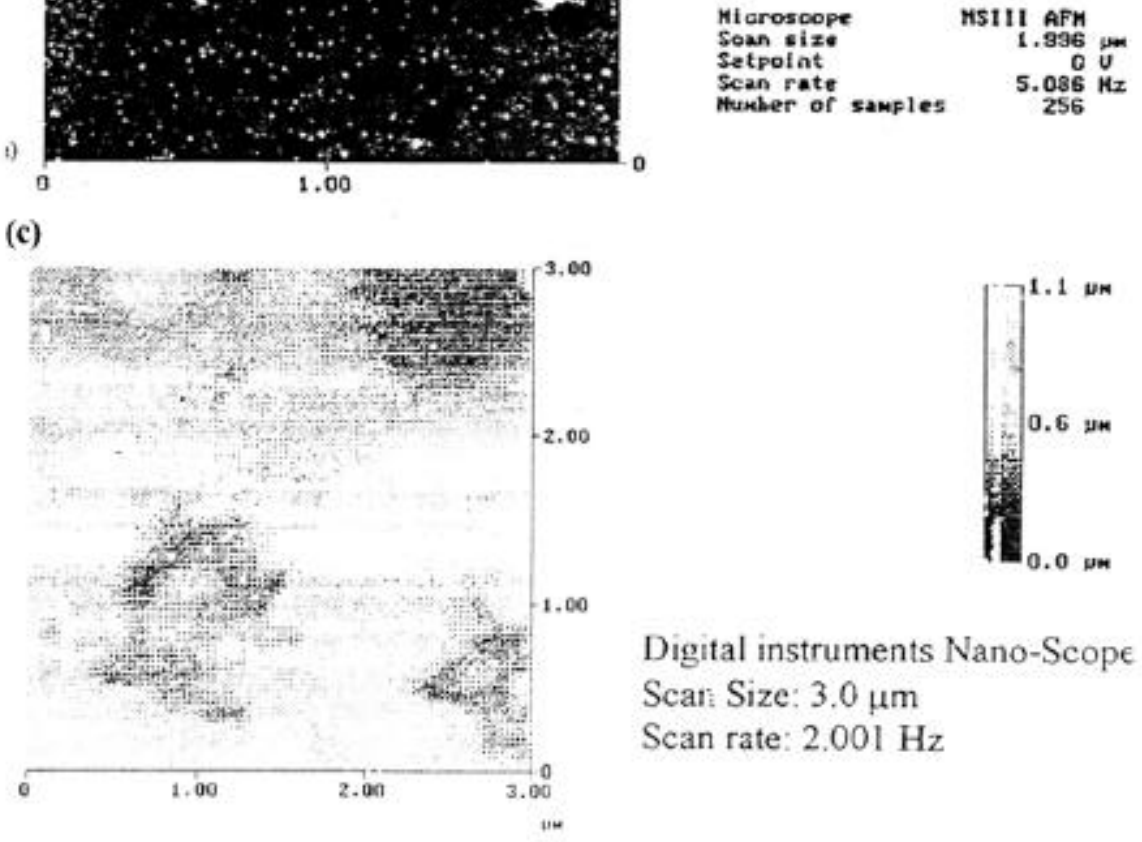

Figure 7. a-c.

Digital instruments Nano-Scope

Scar: Size: $3.0 \mu \mathrm{m}$

Scan rate: $2.001 \mathrm{~Hz}$

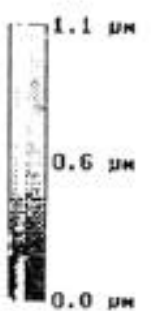


talline forms belong to orthorhombic crystalline structure. $\mathrm{Bi}_{2} \mathrm{~S}_{3}$ has orthorhombic crystal structure. $\mathrm{Bi}_{2} \mathrm{~S}_{3}$ in thin film form is a promising semiconducting material for optoelectronic devices as its band gap energy lies in the range $1 \cdot 2-1.7 \mathrm{eV}$ (Peter 1979). The electrical resistivity of $\mathrm{Bi}_{2} \mathrm{~S}_{3}$ is of the order of $10^{4} \Omega . \mathrm{cm}$. It is useful in the conversion of solar energy into electrical energy by means of PEC process (Miller and Heller 1976). It can also be used in heterojunction, IR detectors, Lux meters, switching devices, Schottky barrier etc. The films of $\mathrm{Bi}_{2} \mathrm{~S}_{3}$ were deposited by Ahire et al (2001a, b). Scanning electron micrograph of $\mathrm{Bi}_{2} \mathrm{~S}_{3}$ is shown in figure 6 . The films are dense, smooth and of compact structure, consist of fine particles. Figure 7 shows the 2D and $3 \mathrm{D} A F M s \mathrm{Bi}_{2} \mathrm{~S}_{3}$ film.
The film appears to be made up of fine particles or nanoparticles.

5.1k Molybdenum disulfide $\left(\mathrm{MoS}_{2}\right)$ : Molybdenum disulphide belongs to VIb-VIa compound semiconductor materials. It has hexagonal crystal structure. Molybdenum disulfide exhibits layer type structure, in which monolayers of Mo are sandwiched between monolayers of sulphur, which are held together by relatively week Van der Waals forces. The optical and electronic properties of layered VI transition metal chalcogenide for efficient solar energy conversion, with low energy direct transition $\left(\alpha=10^{5} \mathrm{~cm}^{-1}\right)$ at photon energy around $1.78 \mathrm{eV}$ shows promise to convert solar energy in thin film structures. The electrical

(d)
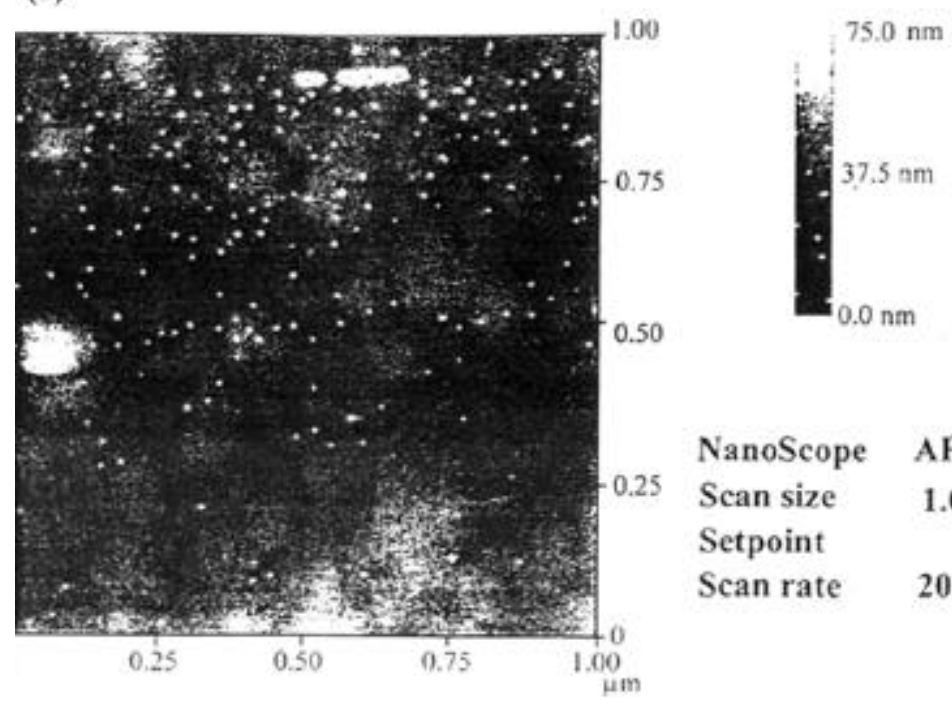

NanoScope AFM

Scan size $\quad 1.000 \mu \mathrm{m}$

Setpoint $0 \mathrm{~V}$

Scan rate $\quad 20.35 \mathrm{~Hz}$

(e)
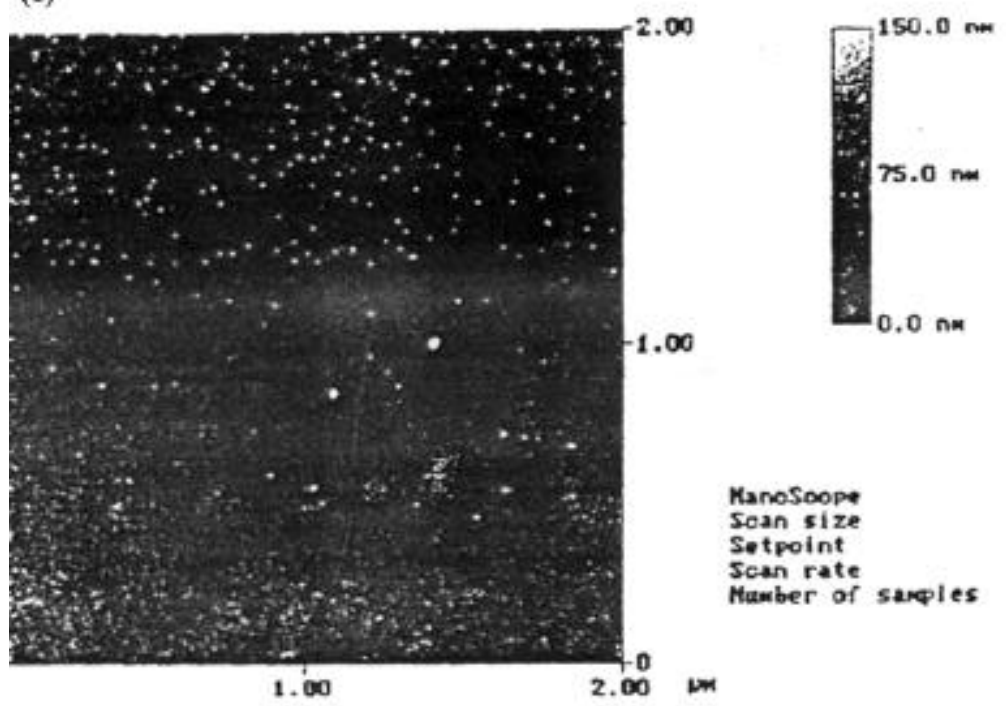

Figure 7. Typical AFMs of SILAR deposited (a) $\mathrm{Bi}_{2} \mathrm{~S}_{3}$, (b) $\mathrm{Sb}_{2} \mathrm{~S}_{3}$, (c) $\mathrm{CuInS}_{2}$, (d) $\mathrm{Bi}_{2} \mathrm{Se}_{3}$ and (e) $\mathrm{Sb}_{2} \mathrm{Se}_{3}$ thin films. 

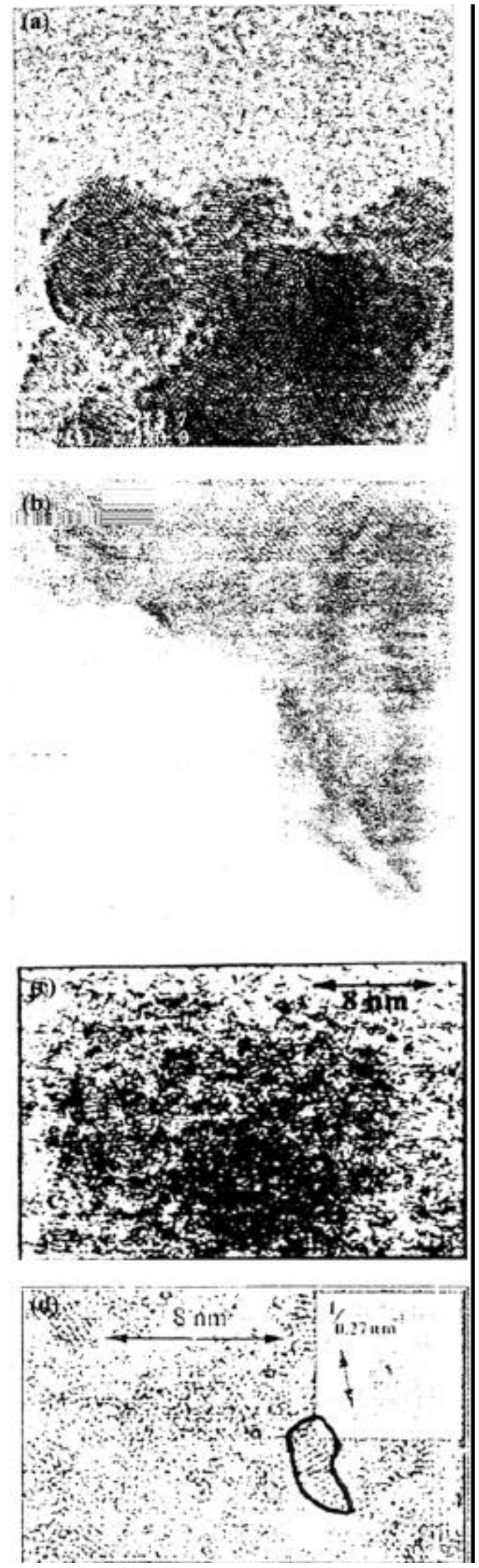

Figure 8. Typical HRTEMs of (a) CdS, (b) $\mathrm{Zn}_{x}(\mathrm{O}, \mathrm{S})_{\mathrm{y}},(\mathbf{c}) \mathrm{Cu}_{2} \mathrm{~S}$ and (d) $\mathrm{CuInS}_{2}$ thin films. resistivity of the $\mathrm{MoS}_{2}$ film is of the order of $10^{4} \Omega \mathrm{cm}$. Molybdenum disulphide appears to be very promising semiconductor material for various applications such as solar cells, rechargeable batteries and solid lubricants for metallic and ceramic surfaces, high vacuum or high temperature applications. They have also been widely used in space technology where their low coefficient of friction in vacuum is of particular value. These applications exist from the optical, electrical and mechanical properties of this compound. The $\mathrm{MoS}_{2}$ thin films were deposited by Sartale and Lokhande (2001a). X-ray diffraction patterns of $\mathrm{MoS}_{2}$ films deposited onto amorphous glass, FTO coated glass and $\mathrm{Si}$ (111) wafer substrates are shown in figure 5A (i-iii). It was observed that films deposited onto amorphous glass substrate are nanocrystalline consisting of fine grains. However, films deposited onto FTO and $\mathrm{Si}$ substrates are microcrystalline.

5.11 Manganese sulphide: Manganese sulphide ( $\mathrm{MnS}$ ) belongs to VII-VI compound semiconductor materials. During recent years, dilute magnetic semiconducting materials have become a focus of interest as they exhibit an interesting combination of magnetism and semiconductivity (Lokhande et al 1998a). MnS is such a material with band gap energy, $E g=3 \cdot 1 \mathrm{eV}$, having potential use in solar cell applications as a window/buffer material. The cubic $\alpha$-phase of $\mathrm{MnS}$ appears to be stable above room temperature, but when they turned to $\alpha$-phase of $\mathrm{MnS}$, they can be prepared at low temperature. The $\gamma$-phase of $\mathrm{MnS}$ can be prepared at low temperature, but they turned to $\alpha$-phase above $200^{\circ} \mathrm{C}$. The $\alpha$-phase is retained at all temperatures (Madelung 1984; Giriat and Furdyana 1988). The deposition of $\mathrm{MnS}$ thin films was carried out by Pathan et al (1999a,b). Plots of optical absorption against wavelength (inset) and $(\alpha h v)^{2}$ against $h v$ for SILAR deposited MnS thin films are shown in figure 9.

Manganese disulphide $\left(\mathrm{MnS}_{2}\right)$ also belongs to VII-VI compound semiconductor materials. $\mathrm{MnS}_{2}$ has a goldenyellow colour. The optical band gap is around $3 \cdot 1 \mathrm{eV}$. The electrical resistivity of the film is of the order of $10^{6}-10^{7} \Omega \mathrm{cm}$ with $p$-type electrical conductivity. Pyrite type phase of $\mathrm{MnS}_{2}\left(p-\mathrm{MnS}_{2}\right)$ has an anti-ferromagnetic ordering of the third kind $\left(\mathrm{AF}_{3}\right)$ below $48 \mathrm{~K}$ involving a doubling of the chemical cell in the direction where the moments alternate. $\mathrm{MnS}_{2}$ could be regarded as an essentially ionic compound. $p-\mathrm{MnS}_{2}$ is rather compressed with a bulk modulus of $76 \mathrm{GPa}$, and that a pressure effect includes at about $14 \mathrm{GPa}$ a structure transition from the pyrite to marcasite-type phase accompanied by a large volume concentration (15\%). The deposition of $\mathrm{MnS}_{2}$ has been reported (Pathan et al 1999a; Kulkarni et al 2002).

5.1m Ferrous sulphide: Ferrous sulphide belongs to VIII-VI compound semiconductor materials. The optical band gap of $\mathrm{FeS}_{2}$ is $3 \mathrm{eV}$. Due to their high absorption coefficient, $\left(10^{5} \mathrm{~cm}^{-1}\right)$ and semiconducting nature, $\mathrm{FeS}_{2}$ is a 
promising candidate for ultra thin solar cells, as very little material is needed and the contact materials do not have quality optoelectronic materials. $\mathrm{FeS}_{2}$ thin films have been deposited by Salunkhe et al (1999).

5.1n Cobalt sulphide: Cobalt sulphide belongs to VIII-VI compound semiconductor materials. Films are of black colour. Cobalt sulphide $(\mathrm{CoS})$ is a semiconductor with band gap energy equal to $0.9 \mathrm{eV}$, however, $\mathrm{Co}_{3} \mathrm{~S}_{4}$ has optical band gap of about $0.78 \mathrm{eV}$. Electrical resistivity of $\mathrm{CoS}$ is of the order $10^{4}-10^{6} \Omega \mathrm{cm}$. Cobalt sulphide has potential applications in solar selective coatings, IR detectors and as a storage electrode in photoelectrochemical storage device (Basu and Pramanik 1986). CoS films are deposited by Sartale and Lokhande (2000c).

5.1o Nickel sulphide: Nickel sulphide belongs to VIIIVI compound semiconductor materials. It has hexagonal crystal structure. The films are black in colour. The optical band gap is $0 \cdot 35-0 \cdot 8 \mathrm{eV}$. Electrical resistivity is of the order of $10-10^{4} \Omega \mathrm{cm}$. Nickel sulphide films have a number of applications in various devices such as solar selective coatings, solar cells, photoconductors, sensors, IR detectors, as an electrode in photoelectrochemical storage device etc (Pramanik and Biswas 1986). The thin films of NiS were deposited by Sartale and Lokhande (2001b).

5.1p Lanthanum sulphide: Lanthanum sulphide belongs to III-VI compound semiconductor materials. This system is more complicated in the sense that four well known

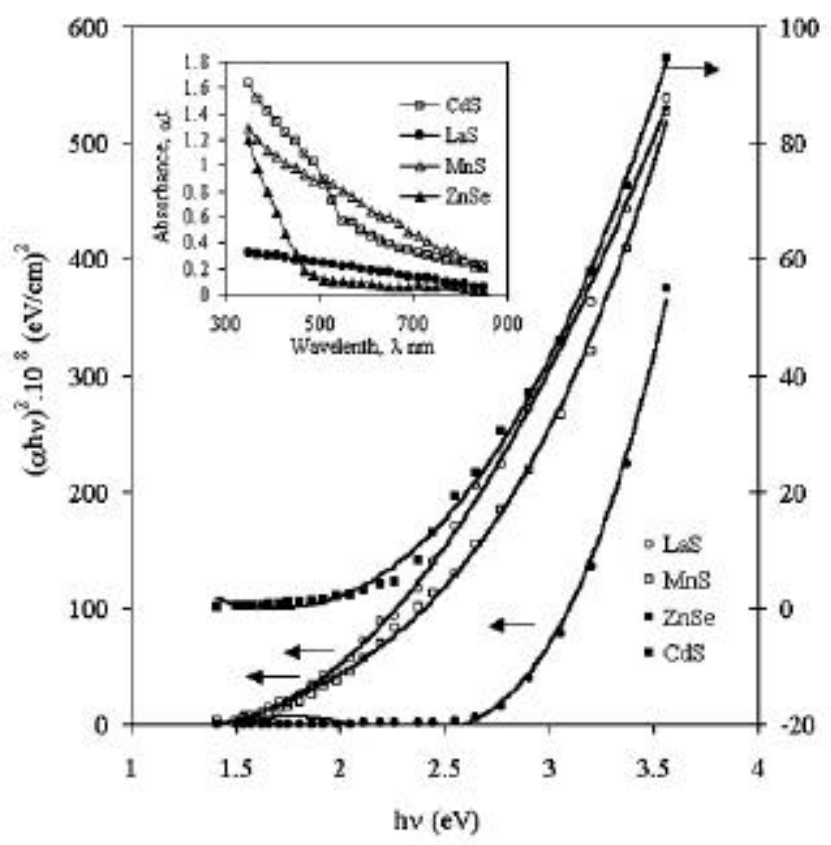

Figure 9. Typical plots of optical absorption against wavelength (inset) and $(\alpha h v)^{2}$ against $h v$ for SILAR deposited CdS, $\mathrm{LaS}, \mathrm{MnS}$ and $\mathrm{ZnSe}$ thin films. phases, $\mathrm{La}_{1.94} \mathrm{~S}, \mathrm{LaS}_{2}, \mathrm{La}_{2} \mathrm{~S}_{3}$ and $\mathrm{La}_{5} \mathrm{~S}_{7}$, are known to exist by creating lanthanum vacancy. The cubic to tetragonal distortion of the unit cell found in crystal and close to stoichiometric $\mathrm{La}_{3} \mathrm{~S}_{4}$ was of Jahn-Teller band type. The films are yellow in colour. The optical band gap is $\sim 2.5 \mathrm{eV}$. Electrical resistivity is found to be of the order of $10^{4}-10^{5} \Omega \mathrm{cm}$ with $p$-type electrical conductivity. $\mathrm{La}_{3} \mathrm{~S}_{4}$ was a strong coupling superconductor with a BCS coherence length, 132 A. Superconducting (Berkley et al 1988), $\gamma-\mathrm{La}_{2} \mathrm{~S}_{3}$ films were used in infrared transmitting material for window applications (Kunta et al 1993). Thin films and rare earth chalcogenide were used in rare earth alloy preparation, superconducting, magnetic cooling, magnetic thin films, photovoltaic devices, thermoelectric devices, for infrared transmitting window materials etc. The films are deposited by Kulkarni et al (2003). Plot of optical absorption against wavelength (inset) and $(\alpha h v)^{2}$ against $h v$ for SILAR deposited lanthanum sulphide thin films is shown in figure 9. Figure 10 shows the plot of $\log \rho$ against (1000/ $T$ ) for SILAR deposited lanthanum sulphide thin films.

\subsection{Metal selenide thin films}

5.2a Copper selenide: Copper selenide belongs to I-VI compound semiconductor materials. Copper selenide usually exists as copper (I) selenide $\left(\mathrm{Cu}_{2} \mathrm{Se}\right.$ or $\left.\mathrm{Cu}_{2-x} \mathrm{Se}\right)$ or copper (II) selenide ( $\mathrm{CuSe}$ or $\left.\mathrm{Cu}_{3} \mathrm{Se}_{2}\right) . \mathrm{Cu}_{3} \mathrm{Se}_{2}$ is often reported as an impurity phase along CuSe. Copper (I) selenide exists in the cubic, tetragonal, orthorhombic or monoclinic

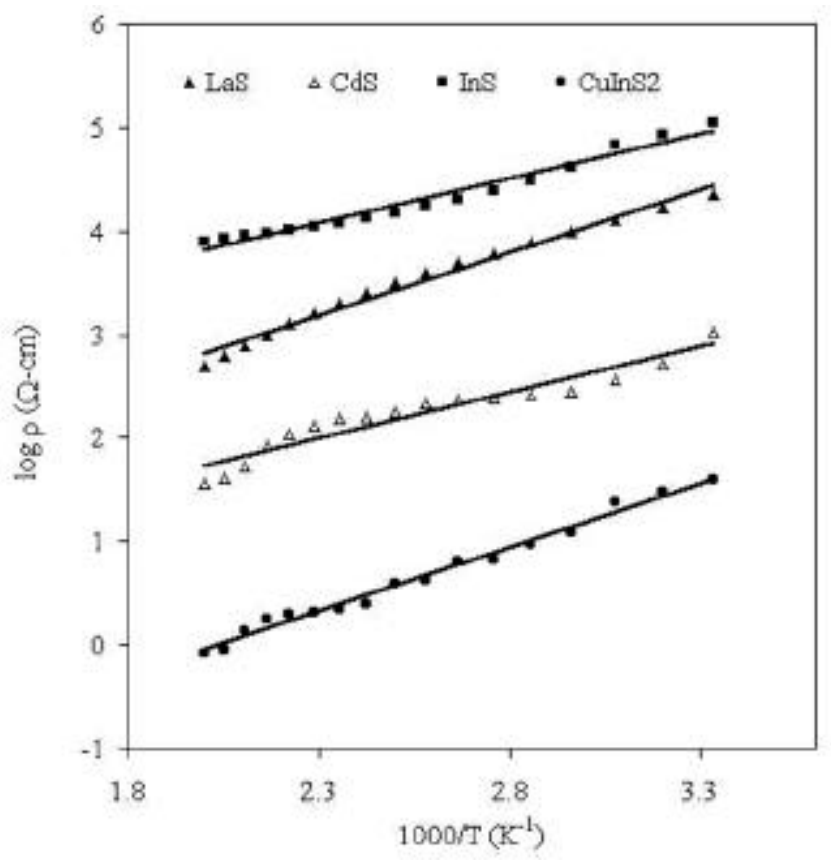

Figure 10. Typical plot of $\log \rho$ against (1000/T) for LaS, CdS, InS and $\mathrm{CuInS}_{2}$ thin films. 
forms. The interest for copper selenide semiconducting thin film is motivated by its application in solar cell technology (Loferski 1956; Okimura et al 1980; Chen et al 1985). The complexity of composition of copper selenide has always lead to the search for more chemically stable forms with better electronic properties. This material usually exists as a copper (I) selenide $\left(\mathrm{Cu}_{2} \mathrm{Se}\right.$ or $\left.\mathrm{Cu}_{2-x} \mathrm{Se}\right)$ (Shafizade et al 1976; Toneje and Toneje 1981; Padam 1987; Kashida and Akai 1988; Haram et al 1992; LevyClement et al 1997) or copper (II) selenide (CuSe or $\mathrm{Cu}_{3} \mathrm{Se}_{2}$ ) (Shafizade et al 1978; Mondal and Pramanik 1983, 1984; Estrada et al 1994). Copper selenide finds applications as solar cell material and super-ionic conductor (Okimura et al 1980; Chen et al 1985; Korzhuev 1998). Copper (I) selenide exists in cubic, tetragonal or orthorhombic or monoclinic forms. Orthorhombic copper (I) selenide can be converted to its cubic phase by heating the material or by electrochemical polarization. This phase transition is also possible at room temperature, by controlling the selenium concentration (Haram and Santhanam 1994). The monoclinic/orthorhombic form of $\beta-\mathrm{Cu}_{2-x} \mathrm{Se}(E g=1.4 \mathrm{eV})$ might be used as a $p$-type window material for solar cells and the cubic form $\left(\alpha-\mathrm{Cu}_{2-x} \mathrm{Se}\right)$ is a high temperature phase (Bickulova et al 1995). $\mathrm{Cu}_{2-x} \mathrm{Se}$ is a semiconductor having cubic Fm3M structure with lattice constant, $\alpha=5.76 \AA$ and is used as a window material in $\mathrm{Cu}_{2-x} \mathrm{Se} / \mathrm{Si}$ solar cells. Deposition of $\mathrm{Cu}_{2} \mathrm{Se}$ has been reported by Pathan et al (2003a). Typical scanning electron micrograph of copper selenide is shown in figure $6(\mathrm{f})$.

5.2b Silver selenide: Silver selenide belongs to I-VI compound semiconductor materials. The films are blackish in colour. The optical band is $\sim 1.2 \mathrm{eV}$. Silver selenide is a well-known super-ionic conductor. It has been used as thermochromic material for non-linear optical devices, photo-chargeable secondary batteries and multipurpose ion-selective electrodes. The deposition of $\mathrm{Ag}_{2} \mathrm{Se}$ was carried out by Pathan and Lokhande (2001b).

5.2c Zinc selenide: Zinc selenide belongs to II-VI compound semiconductor materials. It has cubic and/or hexagonal crystal structure. The films are yellow-orange in colour. The optical band is $2 \cdot 6-3 \cdot 1 \mathrm{eV}$. The electrical resistivity is of the order of $10^{4}-10^{12} \Omega \mathrm{cm}$. The film shows $n$ type electrical conductivity. ZnSe has several advantages: the band gap of $\mathrm{ZnSe}(2.67 \mathrm{eV})$ is wider than that of the CdS $(2.42 \mathrm{eV})$ and allows transition of higher energy photons compared to $\mathrm{CdS}$. In addition, $\mathrm{ZnSe}$ has a better lattice match with $\mathrm{Cu}(\mathrm{InGe}) \mathrm{Se}_{2}$ thin film absorber in band gap range $1.3-1.5 \mathrm{eV}$. $\mathrm{ZnSe}$ is semiconducting that has large potential applications in thin films like photoluminescence and electroluminescent devices and as an $n$-type window layer for thin film heterojunction solar cells. $\mathrm{ZnSe}$ is an attracting material as based solar cells, as it is Cd free (Lokhande et al 1998b). It is also used in IR optics, scintillater and substrate modulators. The deposition of
ZnSe was carried out by Sankapal et al (1999b). Plots of optical absorption against wavelength (inset) and $(\alpha h v)^{2}$ against $h v$ for SILAR deposited $\mathrm{ZnSe}$ thin film are shown in figure 9.

5.2d Cadmium selenide ( $\mathrm{CdSe}$ ): CdSe is a II-VI semiconductor compound. It has wurtzite (hexagonal) and/or cubic crystal structure. The density of CdSe is $5.674 \mathrm{~g} / \mathrm{cm}^{3}$. The optical band gap is $1.7 \mathrm{eV}$. The electrical resistivity is of the order of $10^{4} \Omega \mathrm{cm}$. The film shows $n$-type electrical conductivity. Cadmium selenide has shown great promise as a photo-conductor and solar energy material. These films have applications in manufacture of electronic devices: thin film transistors and $\gamma$-ray detectors. It is also used in IR optics, polarizers, substrates, detectors and sources for vacuum deposition. The deposition of cadmium selenide thin film using SILAR method was carried out by Sankapal et al (1999c).

5.2e Indium selenide: Indium selenide belongs to III-VI compound semiconductor materials. $\mathrm{In}_{2} \mathrm{Se}_{3}$ is a complex hexagonal layered semiconductor with a direct band gap of $1.42 \mathrm{eV}$ and an indirect band gap of $1.29 \mathrm{eV}$. The electrical resistivity is of the order of $10^{7} \Omega \mathrm{cm}$ with $n$-type electrical conductivity. $\operatorname{In}_{2} \mathrm{Se}_{3}$ have been grown recently and characterized for making positive electrodes in new micro-devices like capacitors or micro-batteries with solid electrolytes exhibiting fast ionic conductivity (Kleitz et al 1983). It is of interest because of its polymorphism and related metal ion defect structure. $\mathrm{In}_{2} \mathrm{Se}_{3}$ exhibits atleast three different crystalline modifications denoted as $\alpha, \beta$ and $\gamma$ transition, temperature of 200 and $650^{\circ} \mathrm{C}$, respectively for $\alpha \rightarrow \beta$ and $\beta \rightarrow \gamma$ transition (Ballkanski et al 1983). The films were deposited by Pathan and Lokhande (2003b).

5.2f Antimony selenide: Antimony selenide belongs to V-VI compound semiconductor materials. Antimony trisulphide is layer-structured semiconductor with orthorhombic crystal structure. $\mathrm{Sb}_{2} \mathrm{Se}_{3}$ thin films have attracted wide attention, due to their good photovoltaic properties and high thermoelectric power (TEP), which allow possible applications for optical and thermoelectric cooling devices. The specific resistance of amorphous $\mathrm{Sb}_{2} \mathrm{Se}_{3}$ is of the order of $10^{7} \Omega \mathrm{cm}$ with an optical band gap of $1.88 \mathrm{eV}$. The crystal structure of $\mathrm{Sb}_{2} \mathrm{Se}_{3}$ is orthorhombic. Antimony trisulphide semiconductor thin films were used to improve efficiency and stability in PEC solar cell configuration. The deposition of antimony selenide was carried out by Sankapal et al (2000d). X-ray diffraction pattern of $\mathrm{Sb}_{2} \mathrm{Se}_{3}$ films deposited onto amorphous glass is shown in figure $5 \mathrm{~b}$ (ii). It was observed that films onto amorphous glass substrate are nanocrystalline consisting of fine grains. 2D and 3D AFMs of $\mathrm{Sb}_{2} \mathrm{Se}_{3}$ film are shown in figure 7(e). The films appear to be made up of fine particles or nanoparticles. 
5.2g Bismuth selenide: Bismuth triselenide is a member of V-VI compound semiconductors. It has hexagonal crystal structure. The optical band gap is around $0.35 \mathrm{eV}$. Electrical resistivity is of the order of $10^{5} \Omega \mathrm{cm}$. It continues to draw considerable interest because of its applications in various fields. In recent years considerable attention has been focused on glasses of $\mathrm{Bi}$ and $\mathrm{Se}$ because of their use in optical and photosensitive devices. Over last two decades, many experimental data have been gathered on electrical, optical and thermoelectrical properties of bismuth material, owing to its applications such as presence of temperature control of laser diode etc (Watanbe et al 1983; Mandal and Savadogo 1991; Yesgude et al 1995). The deposition was carried out by Sankapal et al (2000e). X-ray diffraction pattern of $\mathrm{Bi}_{2} \mathrm{Se}_{3}$ films deposited onto amorphous glass is shown in figure $5 b$ (i). It was observed that films deposited onto amorphous glass substrate are nanocrystalline consisting of fine grains. Figure 7 shows the 2D and 3D AFMs of $\mathrm{Bi}_{2} \mathrm{Se}_{3}$ film. The film appears to be made up of fine particles or nanoparticles.

5.2h Lanthanum selenide: Lanthanum selenide belongs to III-VI compound semiconductor materials. The optical band gap of lanthanum selenide is $\sim 2.45 \mathrm{eV}$. Electrical resistivity is of the order of $10^{4} \Omega \mathrm{cm}$ with $p$-type electrical conductivity. Lanthanum selenide shows remarkably sharp possible peak at $2.1^{\circ}$ at $2.77 \mathrm{eV}$ and a broader and smaller structure at $3.01 \mathrm{eV}$. Since the discovery of high temperature superconductors, great efforts have been made to deposit high quality lanthanum selenide in thin film form. The films are of great interest for application in magnetic, optical, nuclear, semiconductor, photoelectrochemical cells, cold cathode emitter devices, infrared materials, window device formation, electrical switching etc. The films were deposited by Pathan et al (2002a).

\subsection{Metal telluride thin films}

5.3a Copper telluride: Copper telluride belongs to I-VI compound semiconductor materials. Copper telluride $\left[\mathrm{Cu}_{x} \mathrm{Te}\right]$ has different crystal structures depending upon the value of $x$ as an orthorhombic, cubic and tetragonal crystal structure. Generally the films are blue-purple-red in colour. Copper telluride forms different phases viz. CuTe, $\mathrm{Cu}_{2-x} \mathrm{Te}, \mathrm{Cu}_{1.8} \mathrm{Te}, \mathrm{Cu}_{2} \mathrm{Te}$ etc. $\mathrm{Cu}_{x} \mathrm{Te}$ thin films have been found to possess near ideal solar control characteristics. The $\mathrm{Cu}_{x} \mathrm{Te}$ thin films may be used in photo-detectors and in photovoltaic applications. Pathan et al (2003b) have investigated the deposition of $\mathrm{Cu}_{2} \mathrm{Te}$ using SILAR method.

5.3b Cadmium telluride: Cadmium telluride belongs to II-VI compound semiconductor materials. It has cubic zincblende crystal structure. Cadmium telluride receives much attention as absorber material for efficient low cost solar cells. Their advantages include high absorption co- efficient, direct band gap with nearly optimum value of the photovoltaics and good match of the electron affinity efficiency as high as $16 \%$ have been reported and the maximum theoretical efficiency was estimated to be $29 \%$. Also the growth of high quality CdTe is important because of its potential applications in solar energy, X-ray detection, $\gamma$-ray detection, IR optics, substrates, detectors and crystal pieces for vacuum deposition etc. The deposition of cadmium telluride thin films was carried out by Lokhande and Pathan (2001b).

5.3c Indium telluride: Indium telluride is a member of III-VI group semiconducting materials. It $\left(\mathrm{In}_{2} \mathrm{Te}_{3}\right)$ has face centred cubic or hexagonal crystal structure, whereas InTe has tetragonal or cubic crystal structure. The films are blue-grey in colour. The electrical resistivity is around $10^{5} \Omega \mathrm{cm}$ with $n$-type electrical conductivity. $\operatorname{In}_{2} \mathrm{Te}_{3}$ may be used as a buffer layer in $\mathrm{Cu}(\mathrm{In}, \mathrm{Ga}) \mathrm{Se}_{2}$ based solar cells and making positive electrodes in new micro-devices like capacitors or micro-batteries. The deposition of indium telluride thin films was carried out by Pathan and Lokhande (2003b). Scanning electron micrograph of indium telluride is shown in figure 6. The films look smooth and homogeneous without visible pores.

5.3d Lanthanum telluride: Lanthanum telluride belongs to III-VI compound semiconductor materials. It has cubic crystal structure. The optical band gap is $\sim 2.4 \mathrm{eV}$. Electrical resistivity is of the order of $10^{4}-10^{5} \Omega \mathrm{cm}$ with $p$ type electrical conductivity. Single crystal of $\mathrm{LaTe}_{2}$ showing a black metallic luster was obtained which measured up to several $\mathrm{mm}$ in length and width. The existence of solid-solubility indicates that an ion-covalent bonding mechanism rather than a purely metallic bond exists in this compound. The deposition of lanthanum telluride thin films was carried out by Pathan et al (2002a).

\subsection{Metal oxide thin films}

5.4a Copper oxide: Copper oxide belongs to I-VI compound semiconductor material. $\mathrm{Cu}_{2} \mathrm{O}$ is $p$-type which has a direct optical band gap of $2 \mathrm{eV}$. Cuprous oxide, red copper oxide $\left(\mathrm{Cu}_{2} \mathrm{O}\right)$, a non-toxic material, is potentially attractive as an active solar cell material, selective absorber layer and used in oxygen or humidity sensors (Olsen et al 1983; Rai 1988; Ristov et al 1988). Many workers have carried out the deposition of copper oxide (Ristov et al 1985; Tolstoi and Molotilkina 1994; Nair et al 1999) using SILAR method.

5.4b Zinc oxide: Zinc oxide belongs to II-VI compound semiconductor materials. It has wurtzite crystal structure. The optical band gap is $\sim 3.3 \mathrm{eV}$. It has high optical transmittance $(>80 \%)$ in the visible range of radiation. It is thermally as well as chemically stable over 
Table 1. Deposition conditions and properties of metal chalcogenide thin films deposited by SILAR method.

\begin{tabular}{|c|c|c|c|c|c|c|c|c|c|c|c|}
\hline \multirow{2}{*}{$\begin{array}{l}\text { Sr. } \\
\text { no. }\end{array}$} & \multicolumn{2}{|c|}{ Precursors } & \multirow{2}{*}{$\begin{array}{l}\text { Temp } \\
\left({ }^{\circ} \mathrm{C}\right)\end{array}$} & \multirow[b]{2}{*}{ Subs } & \multirow[b]{2}{*}{ Ad } & \multirow[b]{2}{*}{$\mathrm{Ri}$} & \multirow[b]{2}{*}{$\mathrm{Re}$} & \multirow[b]{2}{*}{$\mathrm{Cy}$} & \multirow{2}{*}{$\begin{array}{l}\text { Th. } \\
(\mu \mathrm{m})\end{array}$} & \multirow[b]{2}{*}{ Remarks } & \multirow[b]{2}{*}{ Ref. } \\
\hline & Cationic & Anionic & & & & & & & & & \\
\hline i & $\begin{array}{l}0 \cdot 1 \mathrm{M} \\
\mathrm{CuSO}_{4}+\mathrm{NH}_{3} \\
(\mathrm{pH} \sim 10)\end{array}$ & $\begin{array}{l}0 \cdot 1 \mathrm{M} \\
\mathrm{H}_{2} \mathrm{~N} \cdot \mathrm{CS} \cdot \mathrm{NH}_{2} \\
(\mathrm{pH} \sim 6)\end{array}$ & 27 & $\begin{array}{l}\text { Glass, } \\
\text { Si (111) }\end{array}$ & 20 & 30 & 20 & 25 & $0 \cdot 4$ & $\begin{array}{l}\text { The formed compound was a mixture of } \mathrm{Cu}_{x} \mathrm{~S} \\
\text { with } 1.83 \leq x \leq 1.96 \text { and } \mathrm{Cu}_{2} \mathrm{~S} \text { phases with } \\
\text { hexagonal crystal structure. The optical band- } \\
\text { gap was found to be } 2.36 \mathrm{eV} \text {. The electrical } \\
\text { resistivity was of the order of } 10^{-2} \Omega-\mathrm{cm} \text { with } \\
\text { p-type electrical conductivity. The growth rate } \\
\text { was found to be } 16 \mathrm{~nm} / \text { cycle. }\end{array}$ & $\begin{array}{l}\text { Sartale and } \\
\text { Lokhande } \\
(2000 \mathrm{a})\end{array}$ \\
\hline ii & $\begin{array}{l}6 \cdot 25-50 \mathrm{mM} \\
\mathrm{Cu}\left(\mathrm{CH}_{3} \mathrm{COO}\right)_{2} \\
(\mathrm{pH} \sim 5 \cdot 3-5 \cdot 7)\end{array}$ & $\begin{array}{l}3-25 \mathrm{mM} \\
\mathrm{Na}_{2} \mathrm{~S} \\
(\mathrm{pH} \sim 11)\end{array}$ & 27 & $\begin{array}{l}\text { Glass, } \\
\text { ITO, } \\
\text { CdS }\end{array}$ & $\begin{array}{l}5 \\
\text { to } \\
20\end{array}$ & $\begin{array}{l}75 \\
\text { to } \\
125\end{array}$ & $\begin{array}{l}5 \\
\text { to } \\
20\end{array}$ & - & - & $\begin{array}{l}\text { The depositions were carried out in } \mathrm{N}_{2} \text { atmos- } \\
\text { phere. The films were polycrystalline and } \\
\text { hexagonal } \mathrm{CuS} \text {. Stoichiometry of all the } \mathrm{Cu}_{x} \mathrm{~S} \\
\text { films was } \mathrm{Cu}_{x} \mathrm{~S}(x=1) \text {. The } \mathrm{Cu}_{x} \mathrm{~S} \text { spectrum } \\
\text { showed low transmission above } 800 \mathrm{~nm} \text { and } \\
\text { peak transmission close to } 600 \mathrm{~nm} \text {. The surface } \\
\text { of } \mathrm{Cu}_{x} \mathrm{~S} \text { was rough compared with } \mathrm{CdS} \text { films. }\end{array}$ & $\begin{array}{l}\text { Lindroos } \\
\text { et al }(2000)\end{array}$ \\
\hline iii & $\begin{array}{l}0 \cdot 12 \mathrm{M} \\
\mathrm{CuSO}_{4}+ \\
\mathrm{TEA}+\mathrm{HH} \\
(\mathrm{pH} \sim 5)\end{array}$ & $\begin{array}{l}0 \cdot 05 \mathrm{M} \\
\mathrm{Na}_{2} \mathrm{~S} \\
(\mathrm{pH} \sim 12)\end{array}$ & 27 & Glass & 30 & 50 & 30 & 60 & 0.44 & $\begin{array}{l}\text { The formed compound was single phase of } \\
\mathrm{Cu}_{2} \mathrm{~S} \text { with hexagonal crystal structure. The films } \\
\text { were found to exhibit maximum transmittance } \\
\sim 53 \cdot 4 \% \text { for } \lambda=630 \mathrm{~nm} \text {. The absorption of film } \\
\text { was } 10^{4} \mathrm{~cm}^{-1} \text {. The band gap was } 2 \cdot 33 \mathrm{eV} \text { with } \\
p \text {-type electrical conductivity. The films were } \\
\text { found to be nanocrystalline. The growth rate } \\
\text { of the film was estimated to be } 7 \mathrm{~nm} / \text { cycle. }\end{array}$ & $\begin{array}{l}\text { Pathan et al } \\
\text { (2001a) }\end{array}$ \\
\hline $5.1 \mathrm{~b}$ & $\begin{array}{l}\text { Silver sulphide } \\
0.05 \mathrm{M} \\
\mathrm{AgNO}_{3}+ \\
\text { EDTA } \\
(\mathrm{pH} \sim 8)\end{array}$ & $\begin{array}{l}0 \cdot 4 \mathrm{M} \\
\mathrm{H}_{2} \mathrm{~N} \cdot \mathrm{CS} \cdot \mathrm{NH}_{2} \\
(\mathrm{pH} \sim 6)\end{array}$ & 27 & $\begin{array}{l}\text { Glass, } \\
\text { Si (111) }\end{array}$ & 12 & 10 & 12 & 15 & $0 \cdot 22$ & $\begin{array}{l}\text { The crystallinity was improved significantly } \\
\text { with } \mathrm{Si}(111) \text { substrate. Annealing of films in } \\
\text { air resulted in increase in intensities of existing } \\
\text { planes. SEM showed that etched films were } \\
\text { homogeneous and uniform. The optical band- } \\
\text { gap and electrical resistivity were found to be } \\
1 \cdot 1 \mathrm{eV} \text { and } 10^{4} \Omega \text {-cm, respectively. Photo- } \\
\text { electrochemical study showed that the films } \\
\text { were photoactive and of } n \text {-type electrical con- } \\
\text { ductivity. The growth rate of the film was } \\
14 \mathrm{~nm} / \text { cycle. }\end{array}$ & $\begin{array}{l}\text { Sankapal } \\
\text { et al } \\
(2002 \mathrm{a}) \text {, } \\
\text { Pathan et al } \\
\text { (2001a) }\end{array}$ \\
\hline \multicolumn{12}{|c|}{ 5.1c Zinc sulphide } \\
\hline $\mathrm{i}$ & $\begin{array}{l}5 \mathrm{mM}-5 \mathrm{M} \\
\mathrm{ZnSO}_{4}, \mathrm{ZnCl}_{2} \\
(\mathrm{pH} \sim 3 \cdot 7)\end{array}$ & $\begin{array}{l}5 \mathrm{mM} \mathrm{Na}_{2} \mathrm{~S} \\
(\mathrm{pH} \sim 12)\end{array}$ & - & ITO, Mo & - & - & - & - & - & $\begin{array}{l}\text { Electro-kinetic potential measurement as a } \\
\text { function of concentration and } \mathrm{pH} \text { of reaction } \\
\text { solution was discussed. Thickness of the films } \\
\text { was estimated in situ from the interference } \\
\text { colours of the films. Refractive index was } \\
\text { found to be } n=2.2 \text { for } 623 \mathrm{~nm} \text { film. The struc- } \\
\text { ture of the film on ITO coated glass and on } \\
\text { Mo was polycrystalline cubic having a poor } \\
\text { (111) preferred orientation. Films were non- } \\
\text { porous and with small grains ( } 45 \text { to } 65 \mathrm{~nm} \text { ). }\end{array}$ & $\begin{array}{l}\text { Nicolau and } \\
\text { Minnard } \\
(1988)\end{array}$ \\
\hline ii & $\begin{array}{l}0.1 \mathrm{M} \mathrm{ZnCl}_{2}+ \\
0 \cdot 3 \mathrm{M} \mathrm{TEA} \text { or } \\
\mathrm{EN}(\mathrm{pH} \sim 7 \cdot 7- \\
8 \cdot 1) \text { and } 0 \cdot 1 \mathrm{M} \\
\mathrm{ZnCl}_{2}+0 \cdot 2 \mathrm{M} \\
\mathrm{TEA}(\mathrm{pH} \sim 4 \cdot 5)\end{array}$ & $\begin{array}{l}\mathrm{Na}_{2} \mathrm{~S} \\
(\mathrm{pH} \sim 12)\end{array}$ & 27 & $\begin{array}{l}\text { Glass, } \\
\text { ITO }\end{array}$ & 20 & $\begin{array}{c}100- \\
200\end{array}$ & 20 & - & - & $\begin{array}{l}\text { Influence of the complexing agents on the } \\
\text { morphology and structural properties of depo- } \\
\text { sited film was discussed. The growth was } \\
\text { found to be different, for different substrates. } \\
\text { The growth rate varied between } 0 \cdot 13 \text { and } \\
0 \cdot 27 \mathrm{~nm} / \text { cycle. Annealing slightly improved } \\
\text { the quality of } \mathrm{ZnS} \text { films. The high refractive } \\
\text { indices }(1 \cdot 95-2 \cdot 23) \text { and packing densities } \\
\text { were found }(72-90 \%) \text { in films grown on ITO } \\
\text { with TEA complexed. The } \mathrm{Zn}: \mathrm{S} \text { ratio in the } \\
\text { film was } 0 \cdot 8-0 \cdot 89 \text {. The films were } \\
\text { polycrystalline and presumably cubic. }\end{array}$ & $\begin{array}{l}\text { Lindroos } \\
\text { et al (1998) }\end{array}$ \\
\hline iii & $\begin{array}{l}0 \cdot 1-0 \cdot 2 \mathrm{M} \\
\mathrm{ZnCl}_{2} \\
(\mathrm{pH} \sim 5 \cdot 0-5 \cdot 3)\end{array}$ & $\begin{array}{l}0 \cdot 05-0 \cdot 1 \mathrm{M} \\
\mathrm{Na}_{2} \mathrm{~S} \\
(\mathrm{pH} \sim 12)\end{array}$ & 27 & Polyester & 20 & 120 & 20 & - & - & $\begin{array}{l}\text { The films on polyester substrates prepared } \\
\text { with } \mathrm{SnCl}_{2} \text { solution were amorphous up to } \\
\sim 250 \mathrm{~nm} \text { thickness and above that thickness } \\
\text { of the film was found to be polycrystalline. } \\
\text { The optical band gap was found to be } 3.44 \mathrm{eV} \text {. }\end{array}$ & $\begin{array}{l}\text { Lindroos } \\
\text { et al (1997) }\end{array}$ \\
\hline
\end{tabular}




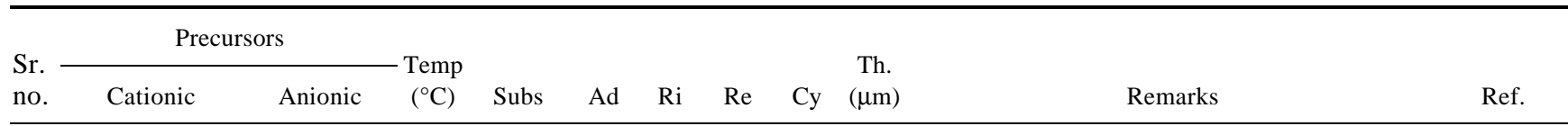

The transmittance was more than $60 \%$ above $400 \mathrm{~nm}$. The growth rate was $0.16 \mathrm{~nm} /$ cycle for $0.1 \mathrm{M} \mathrm{ZnCl}_{2}$ and $0 \cdot 1 \mathrm{M} \mathrm{Na}_{2} \mathrm{~S}$ and $0.22 \mathrm{~nm} /$ cycle when concentration was doubled. EDAX showed $\mathrm{Zn}: \mathrm{S}$ ratio (wt \%) varied from 1.05$1 \cdot 23$. Film consisted of $7-16 \%$ oxygen. The growth of $\mathrm{ZnS}$ on polyester was found to be higher than films deposited on glass, GaAs and ITO substrate using SILAR method.

\begin{tabular}{|c|c|c|c|c|c|c|c|c|c|c|c|}
\hline iv & $\begin{array}{l}0 \cdot 1 \mathrm{M} \\
\mathrm{ZnSO}_{4}+\mathrm{NH}_{3} \\
(\mathrm{pH} \sim 10)\end{array}$ & $\begin{array}{l}0 \cdot 1 \mathrm{M} \\
\mathrm{Na}_{2} \mathrm{~S} \\
(\mathrm{pH} \sim 12)\end{array}$ & 27 & $\begin{array}{l}\text { Glass, } \\
\text { quartz }\end{array}$ & 10 & 15 & 10 & 90 & $0 \cdot 25$ & $\begin{array}{l}\text { The growth rate was found to be } 20 \mathrm{~nm} / \text { cycle. } \\
\text { The film consisted of } \mathrm{Zn}, \mathrm{O}, \mathrm{S} \text { i.e. } \mathrm{Zn}_{x}(\mathrm{O}, \mathrm{S})_{\mathrm{y}} \text {. } \\
\text { The band gap of the film was found to be } \\
3 \cdot 30 \mathrm{eV} \text { which lies between the band gap of } \\
\mathrm{ZnS} \text { and } \mathrm{ZnO} \text {. The electrical resistivity was of } \\
\text { the order of } 10^{6} \Omega-\mathrm{cm} \text {. }\end{array}$ & $\begin{array}{l}\text { Lokhande } \\
\text { et al (2002) }\end{array}$ \\
\hline $\mathrm{v}$ & $\begin{array}{l}0 \cdot 1 \mathrm{M} \mathrm{ZnCl}_{2} \\
0 \cdot 01 \mathrm{M} \mathrm{MnCl}_{2}\end{array}$ & $\begin{array}{l}50 \mathrm{mM} \\
\mathrm{Na}_{2} \mathrm{~S}\end{array}$ & 27 & $\begin{array}{l}\text { Glass, } \\
\mathrm{ITO} \\
\mathrm{Al}_{2} \mathrm{O}_{3} \\
\text { quartz, } \\
\mathrm{CaF}_{2}\end{array}$ & 20 & 20 & 20 & 165 & $0 \cdot 25$ & $\begin{array}{l}\text { The ZnS films were polycrystalline with cubic } \\
\text { structure. The as deposited ZnS : Mn films } \\
\text { were uniform but slightly less smooth } \\
\text { compared with undoped ZnS films. The Mn } \\
\text { level in ZnS film was } 0 \cdot 3 \text { to } 0 \cdot 8 \mathrm{wt} \% \text { using } \\
\text { MnS/ZnS cycle } 1: 100 \text { was achieved. The } \\
\text { growth rate was } 0 \cdot 09 \mathrm{~nm} / \text { cycle. Refractive in- } \\
\text { dices varied from } 2 \cdot 04-2 \cdot 22 \text { and } 2 \cdot 13-2 \cdot 32 \text { on } \\
\text { glass and ITO substrates, respectively. ZnS : Mn } \\
\text { films contained } 20 \text { at } \% \text { oxygen and } 3-15 \text { at } \% \\
\text { hydrogen, but due to annealing their contents } \\
\text { were significantly reduced. }\end{array}$ & $\begin{array}{l}\text { Lindroos } \\
\text { et al (1995) }\end{array}$ \\
\hline \multicolumn{12}{|c|}{ 5.1d Cadmium sulphide } \\
\hline $\mathrm{i}$ & $\begin{array}{l}5 \mathrm{mM} \mathrm{CdSO}_{4} \\
(\mathrm{pH} \sim 8)\end{array}$ & $\begin{array}{l}5 \mathrm{mM} \\
\mathrm{Na}_{2} \mathrm{~S} \\
(\mathrm{pH} \sim 11 \cdot 6)\end{array}$ & 27 & $\begin{array}{l}\text { Glass, } \\
\text { FTO, } \\
\mathrm{Si}, \mathrm{Mo}, \\
\text { Ti, } \\
\mathrm{Ge}, \\
\mathrm{GaAs}, \\
\mathrm{InP} \\
\mathrm{LiNbO}_{3} \\
\mathrm{CaF}_{2}\end{array}$ & 40 & 100 & 40 & - & - & $\begin{array}{l}\text { Water flow rate was } 30 \mathrm{l} / \mathrm{h} \text { and } \mathrm{N}_{2} \text { flow rate } \\
\text { was } 50 \mathrm{l} / \mathrm{h} \text {. Epitaxial films have been grown } \\
\text { on } \mathrm{InP}, \mathrm{Ge} \text {, and GaAs. Polycrystalline hexa- } \\
\text { gonal } \mathrm{CdS} \text { films of optical quality have been } \\
\text { obtained on LiNbO } \mathrm{N}_{3} \text {, FTO-glass, Mo, Ta and } \\
\text { Ti. CdS films of poor quality, inhomogeneous } \\
\text { and irreproducible have been obtained on } \mathrm{Si} \\
\text { and } \mathrm{CaF}_{2} \text {. }\end{array}$ & $\begin{array}{l}\text { Nicolau } \\
(1985)\end{array}$ \\
\hline ii & $\begin{array}{l}5 \mathrm{mM} \\
\mathrm{CdSO}_{4}, \mathrm{CdCl}_{2}\end{array}$ & $\begin{array}{l}5-2 \cdot 8 \mathrm{mM} \\
\mathrm{Na}_{2} \mathrm{~S}\end{array}$ & & $\begin{array}{l}\text { ITO, } \\
\text { Mo, } \\
\text { InP }\end{array}$ & - & - & - & - & - & $\begin{array}{l}\text { Electro-kinetic measurement as a function of } \\
\text { concentration and } \mathrm{pH} \text { of reactant solution was } \\
\text { discussed. CdS films grown on (111) InP } \\
\text { shows differently oriented grains. Films were } \\
\text { of hexagonal type. The structure of CdS film } \\
\text { deposited on ITO coated glass and Mo was } \\
\text { polycrystalline with strong (001) preferred } \\
\text { orientations of stratified grains. The films have } \\
\text { larger grain size from } 30-60 \mathrm{~nm} \text {. The } \mathrm{N}_{2} \text { flow } \\
\text { inside bell jar was kept at } 10 \mathrm{l} / \mathrm{min} \text {. }\end{array}$ & $\begin{array}{l}\text { Nicolau and } \\
\text { Minnard } \\
(1988)\end{array}$ \\
\hline iii & $\begin{array}{l}0 \cdot 125 \mathrm{M} \\
\mathrm{CH}_{3}(\mathrm{COOH})_{2} \\
\mathrm{Cd}(\mathrm{pH} \sim 5) 1 \mathrm{M} \\
\mathrm{CH}_{3}(\mathrm{COOH})_{2} \\
\mathrm{Cd} \text { (non- } \\
\text { aqueous) }\end{array}$ & $\begin{array}{l}0 \cdot 05 \mathrm{M} \\
\mathrm{Na}_{2} \mathrm{~S} \\
(\mathrm{pH} \sim 12) \\
1 \mathrm{M} \\
\mathrm{H}_{2} \mathrm{~N} \cdot \mathrm{CS} \cdot \mathrm{NH}_{2} \\
\text { (non-aqueous) }\end{array}$ & 30 & Glass & 20 & 20 & 20 & 160 & $0 \cdot 28$ & $\begin{array}{l}\text { The films were deposited from aqueous and } \\
\text { non-aqueous media. Films were amorphous } \\
\text { with hexagonal crystal structure. SEM shows } \\
\text { that the films were dense, smooth and homo- } \\
\text { genous without visible porous. Small nano- } \\
\text { particles with diameters } 7-8 \mathrm{~nm} \text { and } 6-7 \mathrm{~nm} \\
\text { were clearly recognized for films from aqueous } \\
\text { and non-aqueous medium, respectively. RBS } \\
\text { spectra concluded that the films were in well } \\
\text { stoichiometric for both the samples along with } \\
\text { presence of oxygen. }\end{array}$ & $\begin{array}{l}\text { Lokhande } \\
\text { et al }(2001)\end{array}$ \\
\hline iv & $\begin{array}{l}0 \cdot 025 \mathrm{M} \\
\mathrm{CH}_{3}(\mathrm{COOH})_{2} \\
\mathrm{Cd}(\mathrm{pH} \sim 5)\end{array}$ & $\begin{array}{l}0 \cdot 1 \mathrm{M} \mathrm{Na}_{2} \mathrm{~S} \\
(\mathrm{pH} \sim 9)\end{array}$ & 80 & Glass & 15 & 10 & 15 & 20 & 28 & $\begin{array}{l}\text { As deposited films were amorphous with } \\
\text { hexagonal structure. Annealing in nitrogen } \\
\text { atmosphere improved the crystallinity of film. } \\
\text { The films were homogenous and covered the } \\
\text { substrate well. The slight decrease in optical }\end{array}$ & $\begin{array}{l}\text { Sankapal } \\
\text { et al } \\
(2000 \mathrm{e})\end{array}$ \\
\hline
\end{tabular}




\begin{tabular}{|c|c|c|c|c|c|c|c|c|c|c|c|}
\hline \multirow{2}{*}{$\begin{array}{l}\text { Sr. } \\
\text { no. }\end{array}$} & \multicolumn{2}{|c|}{ Precursors } & \multirow[b]{2}{*}{$\begin{array}{l}\text { Temp } \\
\left({ }^{\circ} \mathrm{C}\right)\end{array}$} & \multirow[b]{2}{*}{ Subs } & \multirow[b]{2}{*}{$\mathrm{Ad}$} & \multirow[b]{2}{*}{$\mathrm{Ri}$} & \multirow[b]{2}{*}{$\operatorname{Re}$} & \multirow[b]{2}{*}{ Су } & \multirow[b]{2}{*}{$\begin{array}{l}\text { Th. } \\
(\mu \mathrm{m})\end{array}$} & \multirow[b]{2}{*}{ Remarks } & \multirow[b]{2}{*}{ Ref. } \\
\hline & Cationic & Anionic & & & & & & & & & \\
\hline & & & & & & & & & & $\begin{array}{l}\text { band gap }(2.24-2.17 \mathrm{eV}) \text { and electrical resisti- } \\
\text { vity }\left(0.419 \times 10^{5}-0.125 \times 10^{5} \Omega-\mathrm{cm}\right) \text { were } \\
\text { found for annealed films at } 673 \mathrm{~K} .\end{array}$ & \\
\hline $\mathrm{v}$ & $\begin{array}{l}0 \cdot 2 \mathrm{M} \mathrm{CdCl}_{2} \\
(\mathrm{pH} \sim 5)\end{array}$ & $\begin{array}{l}0 \cdot 1 \mathrm{M} \mathrm{Na}_{2} \mathrm{~S} \\
(\mathrm{pH} \sim 12)\end{array}$ & 27 & $\begin{array}{l}\text { ITO, } \\
\text { GaAs }\end{array}$ & 40 & $\begin{array}{c}100- \\
150\end{array}$ & 40 & - & - & $\begin{array}{l}\text { The deposition was carried out in } \mathrm{N}_{2} \text { atmos- } \\
\text { phere. The nominal growth rates were } 0.13 \\
\text { and } 0.078 \mathrm{~nm} / \mathrm{cycle} \text { for the films deposited on } \\
\text { ITO and GaAs (100) substrates, respectively. } \\
\text { The films on both the substrates were found to } \\
\text { be polycrystalline and strongly textured. The } \\
\text { surface looked smooth and uniform. The ave- } \\
\text { rage stoichiometry of CdS on ITO was Cd } 49 \\
\text { and S } 51 \text { at } \% \text {. }\end{array}$ & $\begin{array}{l}\text { Valkonen } \\
\text { et al } \\
(1997 \mathrm{a}, \mathrm{b})\end{array}$ \\
\hline vi & $\begin{array}{l}5 \mathrm{mM} \\
\mathrm{CH}_{3}(\mathrm{COOH})_{2} \\
\mathrm{Cd}(\mathrm{pH} \sim 4 \cdot 5) \\
\text { and } 10 \mathrm{mM} \\
\mathrm{CH}_{3}(\mathrm{COOH})_{2} \\
\mathrm{Mn}(\mathrm{pH} \sim 5)\end{array}$ & $\begin{array}{l}5 \mathrm{mM} \\
\mathrm{Na}_{2} \mathrm{~S} \\
(\mathrm{pH} \sim 12)\end{array}$ & 27 & $\begin{array}{l}\text { Glass, } \\
\text { FTO }\end{array}$ & 20 & 20 & 20 & 165 & $0 \cdot 25$ & $\begin{array}{l}\text { After Mn doping, crystallinity of CdS was } \\
\text { increased. Observed " } d \text { " values were slightly } \\
\text { different than standard " } d \text { " values of CdS. } \\
\text { Optical band gap was } 2.26 \mathrm{eV} \text { for CdS and } \\
2.7 \mathrm{eV} \text { for Mn doped CdS. }\end{array}$ & $\begin{array}{l}\text { Kulkarni } \\
\text { et al (2002) }\end{array}$ \\
\hline \multicolumn{12}{|c|}{ 5.1e Indium sulphide } \\
\hline $\mathrm{i}$ & $\begin{array}{l}0 \cdot 04 \mathrm{M} \\
\mathrm{InCl}_{3} \\
(\mathrm{pH} \sim 4)\end{array}$ & $\begin{array}{l}0 \cdot 1 \mathrm{M} \\
\mathrm{Na}_{2} \mathrm{~S} \\
(\mathrm{pH} \sim 8)\end{array}$ & 27 & Glass & 20 & - & 15 & 50 & $0 \cdot 3$ & $\begin{array}{l}\text { The films were nanocrystalline with cubic struc- } \\
\text { ture. The optical band gap was } 2 \cdot 3 \mathrm{eV} \text {. The elec- } \\
\text { trical resistivity was of the order of } 10^{5} \Omega \text {-cm } \\
\text { with } n \text {-type electrical conductivity. }\end{array}$ & $\begin{array}{l}\text { Pathan } \\
\text { et al } \\
\text { (2001b) }\end{array}$ \\
\hline ii & $\begin{array}{l}0 \cdot 08 \mathrm{M} \\
\mathrm{In}_{2}\left(\mathrm{SO}_{4}\right)_{3} \\
(\mathrm{pH} \sim 5)\end{array}$ & $\begin{array}{l}0 \cdot 1 \mathrm{M} \\
\mathrm{Na}_{2} \mathrm{~S} \\
(\mathrm{pH} \sim 12)\end{array}$ & 27 & Glass & 30 & 50 & 30 & 60 & $0 \cdot 37$ & $\begin{array}{l}\text { The films were nanocrystalline with mixed } \\
\text { phases of InS, In } \mathrm{I}_{2} \mathrm{~S}_{3} \text { and } \mathrm{In}_{6} \mathrm{~S}_{7} \text {. The film has } \\
\text { direct optical band gap of } 2 \cdot 7 \mathrm{eV} \text { with } n \text {-type } \\
\text { electrical conductivity. The film exhibits high } \\
\text { optical absorbance }\left(10^{4} \mathrm{~cm}^{-1}\right) \text {. }\end{array}$ & $\begin{array}{l}\text { Pathan et al } \\
\text { (2001b) } \\
\text { Lokhande } \\
\text { and Pathan } \\
\text { (2001a) }\end{array}$ \\
\hline
\end{tabular}

5.1f Tin sulphide $0 \cdot 2 \mathrm{M}$

$\mathrm{SnCl}_{2}$ $(\mathrm{pH} \sim 2)$

$0 \cdot 1 \mathrm{M} \mathrm{Na}_{2} \mathrm{~S}$ $(\mathrm{pH} \sim 9)$

films on glass were amorphous or consist Sankapa of fine grains, while those on $\mathrm{Si}$ (111) were et al strongly textured with hexagonal crystal struc- (2000c) ture. The optical band gap energy was found to be $2.6 \mathrm{eV}$. The electrical resistivity was of the order of $10^{3} \Omega$-cm. The film showed $n$-type electrical conductivity.

\section{1g Lead sulphide \\ $0 \cdot 1 \mathrm{M}$ \\ $\mathrm{CH}_{3}(\mathrm{COO})_{2}$ \\ $0 \cdot 1 \mathrm{M}$ \\ $\mathrm{Pb}+\mathrm{TEA}$ \\ $\mathrm{CH}_{3} \mathrm{CSNH}_{2}$ $(\mathrm{pH} \sim 7.8))$ \\ $(\mathrm{pH} \sim 4 \cdot 8)$}

27 Glass

$20 \quad 80$

$80 \quad 40$

$800 \quad 0.004$

The films were polycrystalline and highly Kanniainen (100) oriented. The films looked (thickness, et al (2000) $-30 \mathrm{~nm}$ ) continuous but grainy, clearly consist Resch et al of separate particles. LFM have been used to (1997) distinguish local surface properties also. LFM and FM have been used to obtain information about surface coverage.

5.1h Arsenic sulphide

i $\quad 0.1 \mathrm{M} \quad 0.1 \mathrm{M}$ $\mathrm{As}_{2} \mathrm{O}_{3}+$ EDTA $\quad \mathrm{Na}_{2} \mathrm{~S}_{2} \mathrm{O}_{3}$ $(\mathrm{pH} \sim 1)$
80

$\begin{array}{cccccc}\text { Glass, } & 15 & 10 & 15 & 50 & 0 \cdot 3 \\ \text { Si (111) } & & & & & \end{array}$

The films were yellowish in colour and well Sartale and adherent to the substrates. The films deposited Lokhande on glass substrates were amorphous whereas (2000b) those on Si (111) wafer substrate were polycrystalline with monoclinic structure. The bandgap and electric resistivity were found to be $2.38 \mathrm{eV}$ and $10^{5} \Omega$-cm, respectively.

5.1i Antimony sulphide

$$
\begin{array}{lll}
\mathrm{i} & 0.2 \mathrm{M} & 0 \cdot 3 \mathrm{M} \\
& \mathrm{Sb}_{2} \mathrm{O}_{3}+\mathrm{TA} & \mathrm{Na}_{2} \mathrm{~S}_{2} \mathrm{O}_{3} \\
& (\mathrm{pH} \sim 6) &
\end{array}
$$

The films were amorphous or consist of fine Sankapal grain with an orthorhombic crystal structure. et al The optical band gap was $1.8 \mathrm{eV}$. The elec- (1999a) trical resistivity was of the order of $10^{7} \Omega-\mathrm{cm}$. 


\begin{tabular}{|c|c|c|c|c|c|c|c|c|c|c|c|}
\hline \multirow{2}{*}{$\begin{array}{l}\text { Sr. } \\
\text { no. }\end{array}$} & \multicolumn{2}{|c|}{ Precursors } & \multirow{2}{*}{$\begin{array}{c}\text { Temp } \\
\left({ }^{\circ} \mathrm{C}\right)\end{array}$} & \multirow[b]{2}{*}{ Subs } & \multirow[b]{2}{*}{ Ad } & \multirow[b]{2}{*}{$\mathrm{Ri}$} & \multirow[b]{2}{*}{$\mathrm{Re}$} & \multirow[b]{2}{*}{$\mathrm{Cy}$} & \multirow{2}{*}{$\begin{array}{l}\text { Th. } \\
(\mu \mathrm{m})\end{array}$} & \multirow[b]{2}{*}{ Remarks } & \multirow[b]{2}{*}{ Ref. } \\
\hline & Cationic & Anionic & & & & & & & & & \\
\hline \multicolumn{12}{|c|}{ 5.1j Bismuth sulphide } \\
\hline & $\begin{array}{l}0.003 \mathrm{M} \\
\mathrm{Bi}\left(\mathrm{NO}_{3}\right)_{3}+ \\
\mathrm{TEA}(\mathrm{pH} \sim 9)\end{array}$ & $\begin{array}{l}0 \cdot 1 \mathrm{M} \\
\mathrm{CH}_{3} \mathrm{CSNH}_{2} \\
(\mathrm{pH} \sim 11)\end{array}$ & 27 & Glass & 20 & 40 & 20 & 20 & $0 \cdot 14$ & $\begin{array}{l}\text { As deposited films were amorphous. After an- } \\
\text { nealing films turned from amorphous to } \\
\text { polycrystalline, the optical band gap and elec- } \\
\text { trical resistivity for as deposited film were } \\
\text { found to be } 1.78 \mathrm{eV} \text { and } 10^{4} \Omega \text {-cm, respec- } \\
\text { tively. Film showed } n \text {-type electrical con- } \\
\text { ductivity. }\end{array}$ & $\begin{array}{l}\text { Ahire et al } \\
(2001 \mathrm{a}, \mathrm{b})\end{array}$ \\
\hline
\end{tabular}

$5.1 \mathrm{k}$ Molybdenum disulphide $0.001 \mathrm{M}\left(\mathrm{NH}_{4}\right)_{6} \quad 0.2 \mathrm{M} \mathrm{Na}_{2} \mathrm{~S}$ $\mathrm{Mo}_{7} \mathrm{O}_{24}+\mathrm{HCl} \quad(\mathrm{pH} \sim 13 \cdot 5)$ $(\mathrm{pH} \sim 3)$

$\mathrm{CH}_{3}(\mathrm{COO})_{2} \mathrm{Mn} \quad \mathrm{Na}_{2} \mathrm{~S}$ $(\mathrm{pH} \sim 8) \quad(\mathrm{pH} \sim 12)$

\section{ii $\quad 0 \cdot 1 \mathrm{M}$} $\mathrm{MnSO}_{4}$ $0 \cdot 1 \mathrm{M}$ $(\mathrm{pH} \sim 6)$

$\mathrm{Na}_{2} \mathrm{~S}$

Glass $20 \quad 40$

$\begin{array}{ll}0.01 \mathrm{M} & 0.005 \mathrm{M} \\ \mathrm{CH}_{3}(\mathrm{COO})_{2} \mathrm{Mn} & \mathrm{Na}_{2} \mathrm{~S} \\ (\mathrm{pH} \sim 5) & (\mathrm{pH} \sim 12)\end{array}$

Glas

Mo,

20

FTO

5.1 Ferrous sulphide

$\mathrm{m}$
$0 \cdot 4 \mathrm{M}$
$0 \cdot 1 \mathrm{M} \mathrm{Na}_{2} \mathrm{~S}$
Ferric citrate $+(\mathrm{pH} \sim 8 \cdot 5)$
$\mathrm{TEA}+\mathrm{HH}$

$(\mathrm{pH} \sim 10 \cdot 5)$

5.1n Cobalt sulphide

$\begin{array}{ll}0.02 \mathrm{M} & 0.05 \mathrm{M} \mathrm{Na}_{2} \mathrm{~S} \\ \mathrm{CoSO}_{4}+\mathrm{NH}_{3} & (\mathrm{pH} \sim 12)\end{array}$ $(\mathrm{pH} \sim 8)$

\section{1o Nickel sulphide $0 \cdot 1 \mathrm{M} \mathrm{NiSO}_{4}+0.5 \mathrm{M}$ $\mathrm{NH}_{3}(\mathrm{pH} \sim 8) \quad \mathrm{Na}_{2} \mathrm{~S}$ $(\mathrm{pH} \sim 10)$}

$\begin{array}{llllll}\text { Glass, } & 60 & 40 & 60 & 150 & 0 \cdot 1 \\ \text { FTO, } & & & & & \end{array}$

The films were found to be amorphous. Films Salunkhe were annealed up to $673 \mathrm{~K}$ for $30 \mathrm{~min}$, how- et al (1999) ever no significant change was observed. The band gap was found to be $1.1 \mathrm{eV}$ with electrical resistivity of the order of $10^{3} \Omega$-cm. glass were nanocrystalline whereas films onto (2001a) FTO and Si (111) were microcrystalline. The optical bandgap was found to be $1.74 \mathrm{eV}$. The electrical resistivity was of the order of $104 \Omega-\mathrm{cm}$ with $p$-type electrical conductivity.

The films were of $\mathrm{MnS}_{2}$ with cubic crystal Pathan structure. The optical band gap was found to et al be $3 \cdot 1 \mathrm{eV}$. The electrical resistivity was of the (1999a) order of $10^{6} \Omega$-cm with $p$-type electrical conductivity. No significant change was observed after annealing the films in air for $30 \mathrm{~min}$.

The films were of $\mathrm{MnS}_{2}$ with cubic crystal Pathan structure. The optical band gap was found to et al be $2.9 \mathrm{eV}$. The electrical resistivity was of the $(1999 \mathrm{~b})$ order of $10^{5} \Omega$-cm with $p$-type electrical conductivity. The film showed significant increase in crystallinity after annealing the films at $300^{\circ} \mathrm{C}$ for $30 \mathrm{~min}$.

The films were MnS. The optical band gap Kulkarni was $2.9 \mathrm{eV}$ and electrical resistivity was of the et al (2002) order of $10^{5}-10^{6} \Omega . \mathrm{cm}$ with $p$-type electrical conductivity.

in films deposited onto glass substrates Sartale and were amorphous whereas those deposited onto Lokhande $\mathrm{Si}$ (111) wafer were polycrystalline. The band (2000c) gap was found to be of the order of $10^{4} \Omega$-cm with $p$-type electrical conductivity.

formed material was NiS with hexagonal Sartale and crystal structure. The film was homogeneous, Lokhande fine and well covered to the substrate with (2001b) overgrowth of some particles. The optical band gap equal to $0.45 \mathrm{eV}$ was observed. The electrical resistivity was of the order of $10 \Omega-\mathrm{cm}$.

5.1p Lanthanum sulphide $\begin{array}{ll}0 \cdot 1 \mathrm{M} \mathrm{LaCl}_{3} & 0 \cdot 1 \mathrm{M} \mathrm{Na}_{2} \mathrm{~S} \\ (\mathrm{pH} \sim 3) & (\mathrm{pH} \sim 12)\end{array}$

The films were nanocrystalline with $\mathrm{La}_{5} \mathrm{~S}_{7}$ and Kulkarni $\mathrm{La}_{2} \mathrm{~S}_{3}$ phases. The optical band gap was found et al (2003) to be $2.6 \mathrm{eV}$. Electrical resistivity was of the order of $10^{5} \Omega$-cm with $p$-type electrical conductivity. 


\begin{tabular}{|c|c|c|c|c|c|c|c|c|c|c|c|}
\hline \multirow{2}{*}{$\begin{array}{l}\text { Sr. } \\
\text { no. }\end{array}$} & \multicolumn{2}{|c|}{ Precursors } & \multirow{2}{*}{$\begin{array}{l}-\mathrm{Temp} \\
\left({ }^{\circ} \mathrm{C}\right)\end{array}$} & \multirow[b]{2}{*}{ Subs } & \multirow[b]{2}{*}{ Ad } & \multirow[b]{2}{*}{$\mathrm{Ri}$} & \multirow[b]{2}{*}{$\operatorname{Re}$} & \multirow[b]{2}{*}{$\mathrm{Cy}$} & \multirow{2}{*}{$\begin{array}{l}\text { Th. } \\
(\mu \mathrm{m})\end{array}$} & \multirow[b]{2}{*}{ Remarks } & \multirow[b]{2}{*}{ Ref. } \\
\hline & Cationic & Anionic & & & & & & & & & \\
\hline \multicolumn{12}{|c|}{$\begin{array}{l}\text { 5.2 Metal selenide thin films } \\
\text { 5.2a Copper selenide }\end{array}$} \\
\hline & $\begin{array}{l}0 \cdot 12 \mathrm{M} \\
\mathrm{CuSO}_{4}+\mathrm{TA} \\
(\mathrm{pH} \sim 3)\end{array}$ & $\begin{array}{l}0 \cdot 05 \mathrm{M} \\
\mathrm{Na}_{2} \mathrm{SeSO}_{3} \\
(\mathrm{pH} \sim 12)\end{array}$ & 27 & Glass & 30 & 50 & 10 & 65 & $0 \cdot 33$ & $\begin{array}{l}\text { The deposited films were nanocrystalline with } \\
\text { single phase of } \mathrm{Cu}_{2} \mathrm{Se} \text {. The films have direct } \\
\text { band gap of } 2 \cdot 18 \mathrm{eV} \text {. The electrical resistivity } \\
\text { was of the order of } 10^{-2} \Omega-\mathrm{cm} \text { with } p \text {-type } \\
\text { electrical resistivity. }\end{array}$ & $\begin{array}{l}\text { Pathan } \\
\text { et al } \\
(2003 a)\end{array}$ \\
\hline \multicolumn{12}{|c|}{ 5.2b Silver selenide } \\
\hline & $\begin{array}{l}0 \cdot 05 \mathrm{M} \\
\mathrm{AgNO}_{3} \\
(\mathrm{pH} \sim 4)\end{array}$ & $\begin{array}{l}0 \cdot 1 \mathrm{M} \\
\mathrm{Na}_{2} \mathrm{SeSO}_{3} \\
(\mathrm{pH} \sim 12)\end{array}$ & 27 & Glass & 20 & 50 & 20 & 30 & $0 \cdot 25$ & $\begin{array}{l}\text { The films were nanocrystalline. The optical } \\
\text { band gap of the film was found to be } 1 \cdot 3 \mathrm{eV} \text {. }\end{array}$ & $\begin{array}{l}\text { Pathan et al } \\
(2001 \mathrm{~b})\end{array}$ \\
\hline \multicolumn{12}{|c|}{ 5.2c Zinc selenide } \\
\hline & $\begin{array}{l}0 \cdot 2 \mathrm{M} \\
\mathrm{CH}_{3}(\mathrm{COO})_{2} \mathrm{Zn}\end{array}$ & $\begin{array}{l}0 \cdot 1 \mathrm{M} \\
\mathrm{Na}_{2} \mathrm{SeSO}_{3}\end{array}$ & 27 & $\begin{array}{l}\text { Glass, } \\
\text { FTO, } \\
\text { Si(111), } \\
\text { GaP } \\
(111)\end{array}$ & 10 & 10 & 10 & - & - & $\begin{array}{l}\text { Annealing of the film at } 200^{\circ} \mathrm{C} \text { showed } \\
\text { improvement in crystallinity. The optical band } \\
\text { gap was found to be } 2 \cdot 6 \mathrm{eV} \text {. The electrical } \\
\text { resistivity was of the order of } 10^{4} \Omega-\mathrm{cm} \text {. }\end{array}$ & $\begin{array}{l}\text { Sankapal } \\
\text { et al } \\
(1999 b)\end{array}$ \\
\hline \multicolumn{12}{|c|}{ 5.2d Cadmium selenide } \\
\hline & $\begin{array}{l}0 \cdot 2 \mathrm{M} \\
\mathrm{CdSO}_{4}+\mathrm{TA}\end{array}$ & $\begin{array}{l}0 \cdot 1 \mathrm{M} \\
\mathrm{Na}_{2} \mathrm{SeSO}_{3} \\
(\mathrm{pH} \sim 12)\end{array}$ & 27 & $\begin{array}{l}\text { Glass, } \\
\text { FTO }\end{array}$ & 30 & 30 & 30 & 80 & - & $\begin{array}{l}\text { Formed films were CdSe with hexagonal cry- } \\
\text { stal structure. The average ratio of at } \% \text { of } \\
\mathrm{Cd}: \text { Se was } 55: 45 \text {. The optical band gap of } \\
\text { film was found to be } 1.80 \mathrm{eV} \text {. The electrical } \\
\text { resistivity was of the order of } 10^{4} \Omega \mathrm{cm} \text {. The } \\
\text { film showed } n \text {-type electrical conductivity. }\end{array}$ & $\begin{array}{l}\text { Sankapal } \\
\text { et al } \\
(1999 \mathrm{c})\end{array}$ \\
\hline \multicolumn{12}{|c|}{ 5.2e Indium selenide } \\
\hline & $\begin{array}{l}0 \cdot 1 \mathrm{M} \\
\mathrm{In}_{2}\left(\mathrm{SO}_{4}\right)_{3} \\
(\mathrm{pH} \sim 3)\end{array}$ & $\begin{array}{l}0 \cdot 05 \\
\mathrm{Na}_{2} \mathrm{SeSO}_{3} \\
(\mathrm{pH} \sim 12)\end{array}$ & 27 & Glass & 30 & 50 & 10 & 65 & $0 \cdot 41$ & $\begin{array}{l}\text { The films on glass substrates were amorphous } \\
\text { or consisting of fine grains with } \mathrm{InSe}, \mathrm{In}_{2} \mathrm{Se}_{3} \\
\text { and } \mathrm{In}_{6} \mathrm{Se}_{7} \text { phases. The optical band gap energy } \\
\text { was found to be } 2 \cdot 6 \mathrm{eV} \text {. The electrical resis- } \\
\text { tivity was of the order of } 10^{6} \Omega \text {-cm. The films } \\
\text { show } n \text {-type electrical conductivity. }\end{array}$ & $\begin{array}{l}\text { Pathan et al } \\
(2003 \mathrm{~b})\end{array}$ \\
\hline \multicolumn{12}{|c|}{ 5.2f Antimony selenide } \\
\hline & $\begin{array}{l}0 \cdot 2 \mathrm{M} \\
\text { Potassium } \\
\text { antimony tar- } \\
\text { trate }(\mathrm{pH} \sim 5)\end{array}$ & $\begin{array}{l}0 \cdot 1 \mathrm{M} \\
\mathrm{Na}_{2} \mathrm{SeSO}_{3} \\
(\mathrm{pH} \sim 12)\end{array}$ & 27 & Glass & 60 & 40 & 60 & - & - & $\begin{array}{l}\text { The films were nanocrystalline. The optical } \\
\text { band gap was } 1 \cdot 7 \mathrm{eV} \text { with electrical resistivity } \\
\text { of the order of } 10^{5}-10^{6} \Omega-\mathrm{cm} \text {. }\end{array}$ & $\begin{array}{l}\text { Sankapal } \\
\text { et al } \\
(2000 \mathrm{~d})\end{array}$ \\
\hline \multicolumn{12}{|c|}{ 5.2 $\mathrm{g}$ Bismuth selenide } \\
\hline & $\begin{array}{l}0 \cdot 1 \mathrm{M} \text { Bismuth } \\
\text { nitrate }+ \text { TEA } \\
(\mathrm{pH} \sim 8)\end{array}$ & $\begin{array}{l}0 \cdot 1 \mathrm{M} \\
\mathrm{Na}_{2} \mathrm{SeSO}_{3} \\
(\mathrm{pH} \sim 10 \cdot 5)\end{array}$ & 27 & $\begin{array}{l}\text { Glass, } \\
\mathrm{Si}(111)\end{array}$ & 30 & 30 & 30 & 25 & $0 \cdot 18$ & $\begin{array}{l}\text { The film deposited on } \mathrm{Si}(111) \text { showed improve- } \\
\text { ment in crystallinity compared to the films on } \\
\text { the glass substrates. The optical band gap was } \\
\text { found to be } 0 \cdot 38 \mathrm{eV} \text {. The electrical resistivity } \\
\text { was of the order of } 10^{5} \Omega \mathrm{cm} \text {. The decrease in } \\
\text { electrical resistivity was observed after an- } \\
\text { nealing the films. The average grain size was } \\
5-6 \mathrm{~nm} \text {. PEC study confirmed } n \text {-type elec- } \\
\text { trical conductivity of the material. }\end{array}$ & $\begin{array}{l}\text { Sankapal } \\
\text { et al } \\
(2000 \mathrm{e})\end{array}$ \\
\hline \multicolumn{12}{|c|}{ 5.2h Lanthanum selenide } \\
\hline & $\begin{array}{l}0 \cdot 1 \mathrm{M} \\
\mathrm{LaCl}_{3}+\mathrm{TA} \\
(\mathrm{pH} \sim 3)\end{array}$ & $\begin{array}{l}0 \cdot 1 \mathrm{M} \\
\mathrm{Na}_{2} \mathrm{SeSO}_{3} \\
(\mathrm{pH} \sim 12)\end{array}$ & 27 & Glass & 20 & 60 & 20 & 35 & $0 \cdot 25$ & $\begin{array}{l}\text { Films were nanocrystalline with } \mathrm{LaSe}_{2}, \mathrm{La}_{2} \mathrm{Se}_{3} \\
\text { and } \mathrm{La}_{3} \mathrm{Se}_{4} \text { phases. The optical band gap was } \\
2 \cdot 4 \mathrm{eV} \text {. The electrical resistivity was of the } \\
\text { order of } 10^{4} \Omega \text {-cm with } p \text {-type electrical con- } \\
\text { ductivity. }\end{array}$ & $\begin{array}{l}\text { Pathan et al } \\
(2002 \mathrm{a})\end{array}$ \\
\hline \multicolumn{12}{|c|}{$\begin{array}{l}\text { 5.3 Metal telluride thin films } \\
\text { 5.3a Copper telluride }\end{array}$} \\
\hline & $\begin{array}{l}0 \cdot 08 \mathrm{M} \mathrm{CuSO}_{4} \\
(\mathrm{pH} \sim 5)\end{array}$ & $\begin{array}{l}0.05 \mathrm{M} \\
\mathrm{Na}_{2} \mathrm{TeO}_{3} \\
(\mathrm{pH} \sim 3)\end{array}$ & 27 & Glass & 20 & 50 & 20 & 50 & $0 \cdot 36$ & $\begin{array}{l}\text { Films consist of } \mathrm{Cu}_{2-x} \mathrm{Te} \text { and } \mathrm{Cu}_{2} \mathrm{Te} \text { phases. } \\
\text { The optical band gap was } \sim 2 \cdot 2 \mathrm{eV} \text {. Electrical } \\
\text { resistivity was of the order of } 10 \Omega \text {-cm with } \\
\text { p-type electrical conductivity. }\end{array}$ & $\begin{array}{l}\text { Pathan et al } \\
(2003 \mathrm{~b})\end{array}$ \\
\hline
\end{tabular}




\begin{tabular}{|c|c|c|c|c|c|c|c|c|c|c|c|}
\hline \multirow{2}{*}{$\begin{array}{l}\text { Sr. } \\
\text { no. }\end{array}$} & \multicolumn{2}{|c|}{ Precursors } & \multirow{2}{*}{$\begin{array}{l}\text { - Temp } \\
\left({ }^{\circ} \mathrm{C}\right)\end{array}$} & \multirow[b]{2}{*}{ Subs } & \multirow[b]{2}{*}{ Ad } & \multirow[b]{2}{*}{$\mathrm{Ri}$} & \multirow[b]{2}{*}{$\mathrm{Re}$} & \multirow[b]{2}{*}{$\mathrm{Cy}$} & \multirow{2}{*}{$\begin{array}{l}\text { Th. } \\
(\mu \mathrm{m})\end{array}$} & \multirow[b]{2}{*}{ Remarks } & \multirow[b]{2}{*}{ Ref. } \\
\hline & Cationic & Anionic & & & & & & & & & \\
\hline \multicolumn{12}{|c|}{ 5.3b Cadmium telluride } \\
\hline & $0 \cdot 1 \mathrm{M} \mathrm{CdSO}_{4}$ & $\begin{array}{l}0 \cdot 1 \mathrm{M} \\
\mathrm{Na}_{2} \mathrm{TeO}_{3}\end{array}$ & 27 & Glass & 15 & 30 & 15 & 30 & $0 \cdot 26$ & $\begin{array}{l}\text { The films were light grey in colour. Films } \\
\text { were hexagonal and cubic structure. The elec- } \\
\text { trical resistivity was of the order of } 10^{6} \Omega-\mathrm{cm} \text {. }\end{array}$ & $\begin{array}{l}\text { Lokhande } \\
\text { and Pathan } \\
(2001 \mathrm{~b})\end{array}$ \\
\hline \multicolumn{12}{|c|}{ 5.3c Indium telluride } \\
\hline & $\begin{array}{l}0 \cdot 08 \mathrm{M} \\
\mathrm{In}_{2}\left(\mathrm{SO}_{4}\right)_{3} \\
(\mathrm{pH} \sim 5)\end{array}$ & $\begin{array}{l}0 \cdot 05 \mathrm{M} \\
\mathrm{Na}_{2} \mathrm{TeO}_{3} \\
(\mathrm{pH} \sim 3)\end{array}$ & 27 & Glass & 20 & 50 & 20 & 50 & - & $\begin{array}{l}\text { The films consist of single phase of } \mathrm{In}_{2} \mathrm{Te}_{3} \text {. } \\
\text { The optical band gap of the material was } \\
\text { found to be } 1.66 \mathrm{eV} \text {. The electrical resistivity } \\
\text { was of the order of } 10^{-1} \Omega-\mathrm{cm} \text {. }\end{array}$ & $\begin{array}{l}\text { Pathan and } \\
\text { Lokhande } \\
(2003 b)\end{array}$ \\
\hline \multicolumn{12}{|c|}{ 5.3d Lanthanum telluride } \\
\hline & $\begin{array}{l}0.08 \mathrm{M}, \mathrm{LaCl}_{3} \\
(\mathrm{pH} \sim 3)\end{array}$ & $\begin{array}{l}0 \cdot 05 \mathrm{M} \\
\mathrm{Na}_{2} \mathrm{TeO}_{3} \\
(\mathrm{pH} \sim 3)\end{array}$ & 27 & Glass & 30 & 50 & 30 & 45 & - & $\begin{array}{l}\text { A single phase of } \mathrm{La}_{2} \mathrm{Te}_{3} \text { was observed. } \\
\text { Optical band gap was } \sim 2 \cdot 1 \mathrm{eV} \text {. Electrical } \\
\text { resistivity was of the order of } 10^{5} \Omega \text {-cm with } \\
\text { p-type electrical conductivity. }\end{array}$ & $\begin{array}{l}\text { Pathan et al } \\
(2002 \mathrm{a})\end{array}$ \\
\hline \multicolumn{12}{|c|}{$\begin{array}{l}\text { 5.4 Metal oxide thin films } \\
\text { 5.4a Copper oxide }\end{array}$} \\
\hline i & $\begin{array}{l}\mathrm{CuSO}_{4} \text { and } \\
\mathrm{Na}_{2} \mathrm{~S}_{2} \mathrm{O}_{3}\end{array}$ & $\mathrm{NaOH}$ & 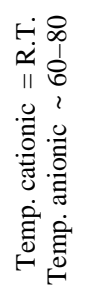 & Glass & $1-2$ & - & $1-2$ & - & $0 \cdot 2$ & $\begin{array}{l}\text { The as-deposited films are polycrystalline and } \\
\text { chemically pure } \mathrm{Cu}_{2} \mathrm{O} \text {. The absorption spec- } \\
\text { trum shows a fundamental absorption edge at } \\
2 \cdot 0 \mathrm{eV} . \mathrm{Cu}_{2} \mathrm{O} \text { films show photoconductivity. }\end{array}$ & $\begin{array}{l}\text { Ristov et al } \\
(1985)\end{array}$ \\
\hline
\end{tabular}

ii $\quad \mathrm{CuSO}_{4}$ and $\mathrm{NaOH}$ $\mathrm{Na}_{2} \mathrm{~S}_{2} \mathrm{O}_{3}$ (1)

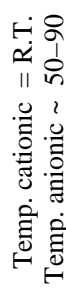

Glass $\quad 20 \quad 20 \quad 20 \quad-\quad 0.45$

The as-deposited films are of cupric structure Nair et al with $\mathrm{Cu}_{2} \mathrm{O}$ composition. Annealing the films (1999) in air at $300^{\circ} \mathrm{C}$ converts these films to $\mathrm{CuO}$. This conversion is accompanied by a shift of the optical band gap from $2 \cdot 1 \mathrm{eV}$ (direct) to $1.75 \mathrm{eV}$ (indirect). The films show $p$-type conductivity, $5 \times 10^{4} \Omega$.cm for a film of thickness $0 \cdot 15 \mu \mathrm{m}$. iii $\mathrm{Cu}$ salt

$\mathrm{H}_{2} \mathrm{O}_{2} / \mathrm{NH}_{3}$

$\mathrm{Si}$ 


\begin{tabular}{|c|c|c|c|c|c|c|c|c|c|c|c|}
\hline \multirow{2}{*}{$\begin{array}{l}\text { Sr. } \\
\text { no. }\end{array}$} & \multicolumn{2}{|c|}{ Precursors } & \multirow{2}{*}{$\begin{array}{c}-\mathrm{Temp} \\
\left({ }^{\circ} \mathrm{C}\right)\end{array}$} & \multirow[b]{2}{*}{ Subs } & \multirow[b]{2}{*}{ Ad } & \multirow[b]{2}{*}{$\mathrm{Ri}$} & \multirow[b]{2}{*}{$\mathrm{Re}$} & \multirow[b]{2}{*}{$\mathrm{Cy}$} & \multirow{2}{*}{$\begin{array}{l}\text { Th. } \\
(\mu \mathrm{m})\end{array}$} & \multirow[b]{2}{*}{ Remarks } & \multirow[b]{2}{*}{ Ref. } \\
\hline & Cationic & Anionic & & & & & & & & & \\
\hline ii & $\begin{array}{l}1 \mathrm{M} \mathrm{ZnSO}_{4}+ \\
15 \mathrm{M} \\
\mathrm{NH}_{4}(\mathrm{OH})\end{array}$ & Water & - & Glass & - & - & - & 35 & $0 \cdot 11$ & $\begin{array}{l}\text { The as deposited film showed hexagonal } \\
\text { (Zincite) structure with preferred orienta- } \\
\text { tions along } c \text {-axis perpendicular to the glass } \\
\text { substrate. The film showed optical band gap, } \\
\text { Eg }=3.42 \mathrm{eV} \text {. Computerized electroneumatic } \\
\text { deposition system was utilized. }\end{array}$ & $\begin{array}{l}\text { Jim'enez- } \\
\text { Gonz'alez } \\
\text { and Nair } \\
(1995) \text {, } \\
\text { Jim'enez- } \\
\text { Gonz'alez } \\
\text { and } \\
\text { Su'arez- } \\
\text { Parra } \\
\text { (1996), } \\
\text { Jim'enez- } \\
\text { Gonz'alez } \\
\text { (1997) }\end{array}$ \\
\hline iii & Zn salt & $\mathrm{H}_{2} \mathrm{O}$ & 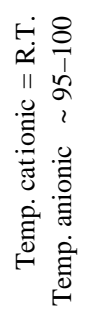 & Glass & - & - & - & - & $>7$ & $\begin{array}{l}\text { As-deposited films are of } \mathrm{ZnO} \text { and } \mathrm{Zn}(\mathrm{OH})_{2} \\
\text { for films with }>1 \mu \mathrm{m}\end{array}$ & $\begin{array}{l}\text { Mitra et al } \\
(1998 \mathrm{a}, \mathrm{b}) \text {, } \\
\text { Chatterjee } \\
\text { et al }(1999)\end{array}$ \\
\hline
\end{tabular}

\begin{tabular}{|c|c|c|c|c|c|c|c|c|c|c|c|}
\hline iv & Zn salt & $\mathrm{H}_{2} \mathrm{O}_{2} / \mathrm{NH}_{3}$ & 20 & $\mathrm{Si}$ & - & - & - & - & 0.014 & As-deposited films are of $\mathrm{ZnO}_{2-x} \cdot n \mathrm{H}_{2} \mathrm{O}$. & $\begin{array}{l}\text { Tolstoy and } \\
\text { Molotilkina } \\
\text { (1994) }\end{array}$ \\
\hline $\mathrm{v}$ & Zn salt & $\mathrm{H}_{2} \mathrm{O}_{2} / \mathrm{KOH}$ & 20 & $\begin{array}{c}\mathrm{SiO}_{2}, \\
\mathrm{Ni}, \\
\mathrm{PVC}, \\
\text { poly- } \\
\text { carbo- } \\
\text { nate }\end{array}$ & - & - & - & - & $0 \cdot 06$ & As-deposited films are of $\mathrm{ZnO}_{2-x} \cdot n \mathrm{H}_{2} \mathrm{O} / \mathrm{Zn}(\mathrm{OH})_{2}$ & $\begin{array}{l}\text { Lindroos } \\
\text { and Leskela } \\
(2000)\end{array}$ \\
\hline
\end{tabular}

5.4c Manganese oxide

\footnotetext{
i $\mathrm{Mn} \quad \mathrm{KMNO}_{4}$

$(\mathrm{CHCOOH})_{2}$,

$\mathrm{MnCl}_{2}$ and

$\mathrm{Mn}\left(\mathrm{NO}_{3}\right)_{3}$

5.4d Cerium oxide

i $\mathrm{Ce}\left(\mathrm{NO}_{3}\right)_{3} \quad \mathrm{H}_{2} \mathrm{O}_{2} / \mathrm{NH}_{3}$

$\mathrm{Ce}\left(\mathrm{CH}_{3} \mathrm{COOH}\right)_{2}$
}

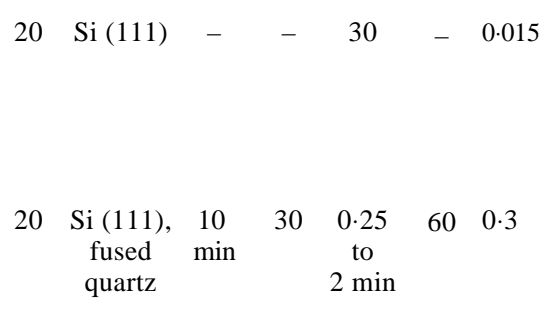
20 Si (111), 10 fused $\mathrm{min}$ quartz
$\begin{array}{llll}30 & 0 \cdot 25 & 60 & 0 \cdot 3\end{array}$
to stage mechanism of layer formation is pro- (1997) posed.

5.5 Ternary sulfide thin films

5.5a Copper indium sulphide

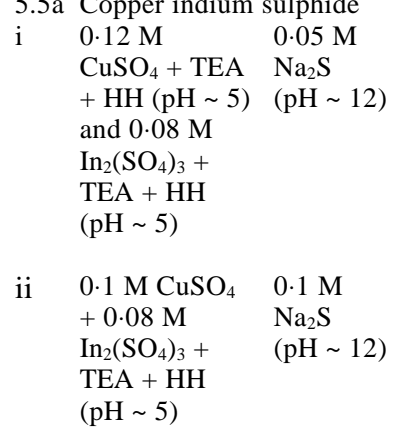

As-deposited films are amorphous. IBM- Tolstoy and compatible computer system was utilized for Ehrlich deposition. The sample do lose water when (1997), heated in air at $200^{\circ} \mathrm{C}$.

Tolstobrov et al (2000)

The multilayer CuS-InS films were deposited Pathan to form $\mathrm{CuInS}_{2}$. The films were nanocry- et al stalline. The optical band gap was found to (2001a) be $1.65 \mathrm{eV}$. The electrical resistivity was Pathan found to be of the order of $10^{3} \Omega-\mathrm{cm}$.

(2002)

27 Glass, $\quad 30 \quad 50 \quad 30 \quad 110 \quad 0.48$ FTO
The films consist of $\mathrm{CuInS}_{2}$ and $\mathrm{CuIn}_{5} \mathrm{~S}_{8}$ pha- Pathan ses. The films were nanocrystalline. The (2002), optical band gap was found to be $1.55 \mathrm{eV}$. Pathan and The electrical resistivity was found to be of Lokhande the order of $10 \Omega-\mathrm{cm}$. 


\begin{tabular}{|c|c|c|}
\hline \multirow{2}{*}{$\begin{array}{l}\text { Sr. } \\
\text { no. }\end{array}$} & \multicolumn{2}{|c|}{ Precursors } \\
\hline & Cationic & Anionic \\
\hline \multirow{5}{*}{$\begin{array}{l}5.5 b \\
\mathrm{i}\end{array}$} & \multicolumn{2}{|c|}{ Cadmium zinc sulphide } \\
\hline & \multicolumn{2}{|c|}{$0.3 \mathrm{M} \quad 0.1 \mathrm{M}$} \\
\hline & \multirow{2}{*}{\multicolumn{2}{|c|}{$\begin{array}{l}\mathrm{CdCl}_{2} \\
(\mathrm{pH} \sim 5 \cdot 1)\end{array}$}} \\
\hline & & \\
\hline & \multicolumn{2}{|l|}{$\begin{array}{l}0 \cdot 4 \mathrm{M} \mathrm{ZnCl}_{2} \\
(\mathrm{pH} \sim 5 \cdot 3)\end{array}$} \\
\hline \multirow[t]{5}{*}{$5.5 \mathrm{c}$} & \multicolumn{2}{|c|}{ Cadmium indium sulphide } \\
\hline & $0 \cdot 1 \mathrm{M}$ & $0.05 \mathrm{M}$ \\
\hline & $\mathrm{CdSO}_{4}$ & $\mathrm{Na}_{2} \mathrm{~S}$ \\
\hline & $\begin{array}{l}(\mathrm{pH} \sim 8) \\
\text { and } 0.04 \mathrm{M}\end{array}$ & $(\mathrm{pH} \sim 12)$ \\
\hline & $\mathrm{InCl}_{3}$ & \\
\hline
\end{tabular}

Ternary selenide thin films

5.5d Copper indium selenide

i $\quad 0.12 \mathrm{M} \quad 0.05 \mathrm{M}$

$\mathrm{CuSO}_{4}+\mathrm{TA} \quad \mathrm{Na}_{2} \mathrm{SeSO}_{3}$

$(\mathrm{pH} \sim 3)$ and $\quad(\mathrm{pH} \sim 12)$

$0.08 \mathrm{M}$

$\mathrm{In}_{2}\left(\mathrm{SO}_{4}\right)_{3}$

$(\mathrm{pH} \sim 3)$

ii $\quad 0.12 \mathrm{M}$

$\mathrm{CuSO}_{4}+\mathrm{TA} \quad \mathrm{Na}_{2} \mathrm{SeSO}_{3}$

$+0.08 \mathrm{M} \quad(\mathrm{pH} \sim 12)$

$\mathrm{In}_{2}\left(\mathrm{SO}_{4}\right)_{3}$

$(\mathrm{pH} \sim 3)$

Ternary telluride thin films

5.5e Copper indium telluride

i $\quad 0.12 \mathrm{M} \mathrm{CuSO}_{4} \quad 0.05 \mathrm{M}$

$(\mathrm{pH} \sim 5)$ and $\mathrm{Na}_{2} \mathrm{TeO}_{3}$

$0.08 \mathrm{M} \mathrm{In}_{2}$

$\left(\mathrm{SO}_{4}\right)_{3}(\mathrm{pH} \sim 5)$

ii $\quad 0.12 \mathrm{M} \quad 0 \cdot 1 \mathrm{M}$

$\mathrm{CuSO}_{4}+\quad \mathrm{Na}_{2} \mathrm{TeO}_{3}$

$0.08 \mathrm{M}$

$\mathrm{In}_{2}\left(\mathrm{SO}_{4}\right)_{3}$

$(\mathrm{pH} \sim 5)$

5.6 Composite thin films

$5.6 \mathrm{a} \mathrm{CdS}-\mathrm{Bi}_{2} \mathrm{~S}_{3}$

$0.06 \mathrm{M}$ cad- $\quad 0.1 \mathrm{M} \mathrm{Na}_{2} \mathrm{~S}$

mium acetate $\quad(\mathrm{pH} \sim 11)$

$(\mathrm{pH} \sim 9) \quad 0.1 \mathrm{M}$

and $0.003 \mathrm{M} \quad \mathrm{CH}_{3} \mathrm{CSNH}_{2}$

bismuth nitrate $(\mathrm{pH} \sim 11)$

$(\mathrm{pH} \sim 11)$

5.6b $\mathrm{Bi}_{2} \mathrm{Se}_{3}-\mathrm{Sb}_{2} \mathrm{Se}_{3}$

$0.1 \mathrm{M} \quad 0.1 \mathrm{M}$

Bismuth nitrate $\mathrm{Na}_{2} \mathrm{SeSO}_{3}$

$(\mathrm{pH} \sim 8) \quad(\mathrm{pH} \sim 8.5)$

and $0.2 \mathrm{M}$

potasium anti-

mony nitrate

$(\mathrm{pH} \sim 5)$
80 Glass, $15 \quad 10 \quad 15 \quad-\quad 0.44$

FTO

Th.

$\left({ }^{\circ} \mathrm{C}\right) \quad$ Subs $\quad$ Ad $\quad \mathrm{Ri} \quad \mathrm{Re} \quad \mathrm{Cy} \quad(\mu \mathrm{m})$

Remarks

Ref.
27 Glass, $20 \quad 100 \quad 20$

ITO $40 \quad 150 \quad 40$

In multilayer CdS/ZnS thin films, both con- Nicolau stituents had cubic structure and (111) was et al (1990) the most intensive reflection. Also, (220) reflection of $\mathrm{ZnS}$ and (222) of $\mathrm{CdS}$ were observed. The sample contained $\mathrm{Cd} 11 \%$, zinc $39 \%$ and sulphur 50 at $\%$. In the $\mathrm{CdS} / \mathrm{ZnS}$ structure the cations do not diffuse from layer to layer but separate films were detected.

\section{$27 \quad$ Glass $\quad 20 \quad 40 \quad 10 \quad 80 \quad 0 \cdot 4$}

The films were nanocrystalline with cubic Pathan et al structure. The film annealed at $573 \mathrm{~K}$ for $15 \mathrm{~min}$ (2001c) showed improved crystallinity. The optical band gap was found to be $2 \cdot 12 \mathrm{eV}$. The electrical resistivity was of the order of $10^{4} \Omega$ $\mathrm{cm}$ with $n$-type electrical conductivity.

Glass, 20
FTO

The multilayer CuSe and InSe films were Pathan deposited to form $\mathrm{CuInSe}_{2}$. The films were (2002), nanocrystalline. The electrical resistivity Pathan and was found to be of the order of $10^{2}-10^{3} \Omega$ - Lokhande $\mathrm{cm}$

(2003a)

$\begin{array}{lllllll}27 & \text { Glass } & 15 & 50 & 15 & 50 & 0 \cdot 48\end{array}$

The multilayer CuTe and InTe films were Pathan deposited to form CuInTe. The films were (2002), nanocrystalline. The electrical resistivity Pathan and was found to be of the order of $10^{3} \Omega \mathrm{cm}$. Lokhande (2003a)

27 Glass, $15 \quad 50 \quad 15 \quad 90 \quad 0 \cdot 52$

The films formed were $\mathrm{CuInTe} \mathrm{T}_{2}$ with tetragonal crystal structure. The films were nanocrystalline. The electrical resistivity was $10-100 \Omega \mathrm{cm}$. films to be nanocrystalline $\mathrm{CuInSe}_{2}$. The films looked smooth and uniform from SEM studies. The electrical resistivity was of the order of $10-100 \Omega-\mathrm{cm}$.

nd

$\begin{array}{lcllllll}27 & \text { Glass, } & 15 & 30 & 15 & 30 & 0 \cdot 14 & \text { Th } \\ \text { FTO } & & & & 20 & & \end{array}$

27 Glass, $\quad 60 \quad 40 \quad 60 \quad 350 \quad 0.185$

The deposited material consisted of hexagonal Ahire et al $\mathrm{CdS}$ and orthorhombic $\mathrm{Bi}_{2} \mathrm{~S}_{3}$ i.e. $(\mathrm{CdS})_{x}\left(\mathrm{Bi}_{2} \mathrm{~S}_{3}\right)_{1-} \quad$ (2001b) $x$. The films showed $n$-type electrical conductivity. Photo-electrochemical properties were also discussed.

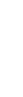


large fluctuations. Its special features like transparency and conductivity dragged it in variety of applications such as energy window, liquid crystal display, solar cells, gas sensors, ultrasonic oscillators, transducers etc (Chopra et al 1983; Paque et al 1983; Belgit et al 1991; Guillemole et al 1991; Mazanc et al 1991; Olvera et al 1993). The electrical resistivity is found to be of the order of $10^{8} \Omega \mathrm{cm}$. The deposition of zinc oxide thin films was carried out by many workers (Ristov et al 1987; Jim'enezGonz'alez and Nair 1995; Tolstobrov and Tolstoi 1995; Jim'enez-Gonz'alez and Su'arez-Parra 1996; Jim'enezGonz'alez 1997; Mitra et al 1998a,b; Chatterjee et al 1999; Lindroos and Leskel“a 2000).

5.4c Manganese oxide: Manganese oxide belongs to VIIVI compound semiconductor material. The optical band gap is $\sim 2.6 \mathrm{eV}$. The films have electrical resistivity between $10^{6}$ and $10^{8} \Omega \mathrm{cm}$. Manganese oxide electrodes have promising character of practical use in water electrolysis, photoelectrochemical cells and superconductivity. The deposition of manganese oxide were carried out by Tolstoy et al (1997).

5.4d Cerium oxide: Cerium oxide belongs to III-VI compound semiconductor material. This compound has an important practical use, as a precursor in the technology of high-temperature superconductors. The deposition of cerium oxide thin film was carried out by Tolstoy and Ehrlich (1997) and Tolstobrov et al (2000).

\subsection{Ternary chalcogenide thin films}

5.5a Copper indium sulphide: Copper indium sulphide belongs to I-III-VI compound semiconductor materials. It has tetragonal and cubic crystal structures. The films are black in colour. It has a crystal bulk band gap around $1.55 \mathrm{eV}$, but on polycrystalline thin film the band gap varies between 1.3 and $1.5 \mathrm{eV}$, which are close to optimum for solar energy conversion. It is a direct band gap semiconductor and it can be obtained in both, $n$ or $p$ type conductivity. The electrical resistivity is $\sim 0 \cdot 1$ to $100 \Omega \cdot \mathrm{cm}$. $\mathrm{CuInS}_{2}$ is a semiconductor that may crystallize both chalcopyrite structures. CuInS $\mathrm{C}_{2}$ material is of particular interest for thin film solar cell applications. The deposition of $\mathrm{CuInS}_{2}$ thin films was carried out by Pathan (2002) and Pathan and Lokhande (2003). Figure 8 shows the highresolution transmission electron micrograph (HRTEM) of $\mathrm{CuInS}_{2}$ thin film. By HRTEM, random orientation of nanoparticles can be clearly seen. Figure 7 shows the 2D and 3D AFMs of $\mathrm{CuInS}_{2}$ thin film. The film appears to be made up of fine particles or nanoparticles. Plot of $\log \rho$ against $(1000 / T)$ for $\mathrm{CuInS}_{2}$ thin film is shown in figure 10.

5.5b Cadmium zinc sulphide: Cadmium zinc sulphide belongs to II-II-VI compound semiconductor materials. It has cubic and/or hexagonal crystal structure. The optical band gap and electrical resistivity are of the order of 2.5 to $3.6 \mathrm{eV}$ and $10^{4}-10^{12} \Omega \mathrm{cm}$, respectively. $\mathrm{Cd}_{x} \mathrm{Zn}_{1-x} \mathrm{~S}$ ternary alloy compound are promising materials for a variety of optical devices applications, such as electroluminescent and photoconductor devices and photovoltaic cells. Solid solution of $\mathrm{CdZnS}$ thin film can be used in solar cells instead of $\mathrm{CdS}$ film, to reduce the mismatch between $\mathrm{CdS}$ and $\mathrm{Cu}_{x} \mathrm{~S}$. The $\mathrm{CdZnS}$ thin films can be used not only with $\mathrm{Cu}_{x} \mathrm{~S}$ but also with different materials such as CdTe, CuInSe ${ }_{2}, \mathrm{CuGaSe}_{2}$ etc. The deposition of $\mathrm{CdZnS}$ thin films was carried out by Nicolau et al (1990).

5.5c Cadmium indium sulphide: Cadmium indium sulphide belongs to II-III-VI compound semiconductor materials. It has spinel cubic structure. The optical band gap is $\sim 2.12 \mathrm{eV}$ and electrical resistivity is of the order of $10^{4} \Omega \mathrm{cm}$ with $n$-type electrical conductivity. Cadmium indium sulphide is photoactive and has received attention as a prospective material for solid state and PEC solar cells. The thin films of $\mathrm{CdIn}_{2} \mathrm{~S}_{4}$ were deposited by Pathan et al (2001c).

5.5d Copper indium selenide: $\mathrm{CuInSe}_{2}$ belongs to the group of I-III-VI ternary chalcopyrite semiconductor compounds, having a band gap of the order of $1 \mathrm{eV}$ and a very high absorption coefficient near the band edge. It is a direct band gap semiconductor and it can be obtained in both, $n$ or $p$ type conductivity. CuInSe $\mathrm{C}_{2}$ and its solid solutions with $\mathrm{CuInGaSe} \mathrm{I}_{2}$ and $\mathrm{CuInS}_{2}$ are among the leading candidates for low cost terrestrial photovoltaic devices. The reported conversion efficiency $(11.0 \%)$ and excellent stability with $\left(\mathrm{Cd}, \mathrm{ZnS} / \mathrm{CuInSe}_{2}\right)$ thin film solar cell, makes the ternary thin film polycrystalline semiconductor, $\mathrm{CuInSe}_{2}$, as a strong candidate for photovoltaic devices. The optical properties of such films are very important in view of the intensive interest in the optoelectronic properties. The CuInSe $\mathrm{C}_{2}$ thin films were deposited by Pathan (2002) and Pathan and Lokhande (2003a).

5.5e Copper indium telluride: Copper indium telluride belongs to I-III-VI compound semiconductor materials. It has tetragonal crystal structure. The films are blackish in colour. The optical band gap is $\sim 0.95 \mathrm{eV}$. Electrical resistivity is of the order of $10-100 \Omega \mathrm{cm}$. It is a direct band gap semiconductor and it can be obtained in both, $n$ or $p$ type conductivity. The $\mathrm{CuInTe}_{2}$ compound semiconductors exhibit chemical and optical properties which make them promising for photovoltaic devices. CuInTe is a direct semiconducting direct band gap ( $E g=0.82-$ $0.96 \mathrm{eV}$ ) material which belongs to ternary $\mathrm{Cu}$ family. The deposition was carried out by Pathan (2002) and Pathan and Lokhande (2003).

\subsection{Composite thin films}

5.6a Cadmium sulphide-bismuth sulphide: Cadmium sulphide and bismuth sulphide are promising semiconducting 
materials in the conversion of the solar energy into electrical energy by means of PEC process. However, if each of them is considered separately, it is impossible to fulfil all the desired requirements of the semiconductor to be used because the band gaps of $\mathrm{CdS}(2.4 \mathrm{eV})$ and $\mathrm{Bi}_{2} \mathrm{~S}_{3}$ $(1.4 \mathrm{eV})$ do lie close to solar energy spectrum maximum. In this respect, new solar energy materials are needed to consider which of them satisfy the technical properties. It is found that by formation of composite films by combination of two semiconductors we get better results in photoconductivity. The films were deposited by Ahire et al (2001b).

5.6b Bismuth selenide-antimony selenide: Compound of the column V-B and VI-B elements in the periodic table with chemical formula $\mathrm{MV}-\mathrm{B}_{2} \mathrm{NVI}-\mathrm{B}_{3}$ basically. These materials cast as semiconductors. Their compounds have been of interest in the study of photoconductivity, photosensitivity and thermoelectric power. The $\mathrm{Bi}_{2} \mathrm{Se}_{3}$ and $\mathrm{Sb}_{2} \mathrm{Se}_{3}$ compounds are the members of the above group of materials. The combination of two may give better result in the application of photosensitivity and photoconductivity. The films were deposited by Sankapal et al (2001). X-ray diffraction pattern of $\mathrm{Bi}_{2} \mathrm{Se}_{3}-\mathrm{Sb}_{2} \mathrm{Se}_{3}$ films deposited onto amorphous glass is shown in figure $5 \mathrm{~b}$ (iii). It was observed that films deposited onto amorphous glass substrate are nanocrystalline consisting of fine grains.

\section{Conclusions}

In the present review article, we have described the successive ionic layer adsorption and reaction (SILAR) method for the deposition metal (binary, ternary, composite etc) chalcogenide thin films. It is concluded that (i) SILAR method can be used to prepare metal chalcogenide thin films, (ii) SILAR is a cheap method, making the process feasible for commercial application, (iii) wastage of material is avoided as no precipitate is formed during this process, (iv) the materials are stoichiometric and (v) doping of semiconductors, desired type for device formation etc can be achieved.

The optimization of various preparative parameters has been tabulated along with film properties. The film properties are well comparable with the properties obtained by other chemical methods. This shows the wide applicability of SILAR method for deposition of various metal chalcogenides. These chalcogenides are technologically important in device formation based on solar selective coatings, solar cells, photoconductive cells etc where large area is desirable. At the same time, SILAR opens a window for the preparation of nanocrystalline films, which are important for finding new applications.

Abbreviations: Ad, Adsorption time; CBD, chemical bath deposition; $\mathrm{Cy}$, total number of deposition cycles;
EN, ethylenediamine; FTO, fluorine doped tin oxide; FM, force modulation microscopy; HH, hydrazine hydrate; ITO, indium doped tin oxide; LFM, lateral force microscopy; PEC, photoelectrochemical; Re, reaction time; Ref, references; $\mathrm{Ri}$, rinsing time; SILAR, successive ionic layer adsorption and reaction; subs, substrate; TA, tartaric acid; TEA, triethanolamine; Temp, deposition temperature; Th, thickness of the film.

\section{Acknowledgements}

Authors are thankful to UGC, New Delhi, for the financial support through DRS (SAP) 1999-2004 programme. One of the authors (HMP) thanks the Department of Physics, Shivaji University, Kolhapur, for the award of a Departmental Research Fellowship.

\section{References}

Agnihotri O P and Gupta B K 1981 Solar selective surfaces (New York: Wiley) p. 130

Ahire R R, Sankapal B R and Lokhande C D 2001a Mater. Res. Bull. 36199

Ahire R R, Sankapal B R and Lokhande C D 2001b Mater. Chem. Phys. 7248

Alexeyev V 1971 Quantitative analysis (Moscow: Mir Publication)

Ballkanski M, Kambas K, Julien C, Hammerberg J and Schleich D 1983 Solid Sate Ionics 5387

Basu P K and Pramanik P 1986 Mater. Sci. Lett. 5216

Belgit K, Subhan M A, Rulhe U, Duchemin S and Bougnot J 1991 Proc. 10th EC photovoltaic conf. (Lissabon, Portugal ) p. 613

Berkley D D, Maps J H, Wan J C and Goldman A M 1988 Thin Solid Films 156271

Bickulova N N, Biskulova V T and Yugafarva Z A 1995 10th Int. conf. solid state ionics, ABSV SSI-10 (Singapore: North Holland Pub.)

Britt J and Ferekides C 1993 Appl. Phys. Lett. 622851

Chatterjee A P, Mitra P and Mukhopadhyay A K 1999 J. Mater. Sci. 344225

Chen W S, Stewark J M and Mickelson R A 1985 Appl. Phys. Lett. 46 1095, 1695

Chopra K L, Major S and Panday D K 1983 Solar Cells 1102

Danko V A, Indutnyi I Z, Kudveryavslav A A and Minko V I 1991 Phys. Status Solidi (a)124 235

Desai J D and Lokhande C D 1994 Thin Solid Films 23729

Dimmler B and Schock H W 1996 Prog. Photovoltaic RES Appl. 4425

Estrada C A, Nair P K, Nair M T S, Zingaro R A and Meryers E A 1994 J. Electrochem. Soc. 141802

Giriat W and Furdyana J K 1988 Semiconductors and semimetals (eds) J K Furdyana and J Kossut (San Diego, CA: Academic Press) p. 25

Grozdanov I and Najdoski M 1995 J. Solid State Chem. 114 469

Guillemole J F, Lincot D, Cowache F and Vedel J 1991 Proc. 10th EC photovoltaic conf. (Lissabon, Portugal) p. 609

Gupta B K, Thangaraj R and Agnihotri O P 1979 Solar Energy Mater. 1471 
Hall R B and Meakin J B 1979 Thin Solid Films 63203

Haram S K and Santhanam K S V 1994 Thin Solid Films 23821

Haram S K, Santhanam K S V, Neumann-Spallert M and LevyClement C 1992 Mater. Res. Bull. 271185

Hodes G, Manassen J and Cahen D 1976 Nature 261403

Jim’enez-Gonz'alez A E 1997 J. Solid State Chem. 128176

Jim'enez-Gonz'alez A E and Nair P K 1995 Semicond. Sci. Technol. 101277

Jim’enez-Gonz'alez A and Su’arez-Parra R 1996 J. Cryst. Growth 167649

Kanniainen T, Lindroos S, Resch R, Leskela M, Friedbacher G and Grasserbauer M 2000 Mater. Res. Bull. 351045

Kashida S and Akai J 1988 J. Phys. C: Solid State Phys. 21 5329

Kleitz M, Sapoval B and Chabre Y 1983 Solid State Ionics 9/10 777

Korzhuev M A 1998 Phys. Solid State 40217

Kulkarni S S, Pathan H M and Lokhande C D 2002 National seminar on materials and devices (Bareilly: MJP, Rohilkhand University)

Kulkarni S S, Sartale S D, Pathan H M and Lokhande C D 2002 National seminar on electro and magneto ceramics devices and systems, Akluj

Kulkarni S S, Pathan H M and Lokhande C D 2003 Annual general meeting and theme symposium on novel polymeric materials (Mumbai: BARC)

Kunta P N, Dravid V P and Risbud S H 1993 Philos. Mag. B93 67

Levy-Clement C, Neumann-Spallart M, Haram S K and Santhanam K S V 1997 Thin Solid Films 302112

Lincot D and Borges R O 1992 J. Electrochem. Soc. 1391880

Lindroos S and Leskel“a M 2000 Int. J. Inorg. Mater. 2197

Lindroos S, Kanniainen T, Leskela M and Rauhala E 1995 Thin Solid Films 26379

Lindroos S, Kanniainen T and Leskela M 1997 Mater. Res. Bull. 321631

Lindroos S, Charreire Y, Bonnin D and Leskela M 1998 Mater. Res. Bull. 33453

Lindroos S P, Arnold A and Leskela M 2000 Appl. Surf. Sci. 15875

Loferski J J 1956 J. Appl. Phys. 27777

Lokhande C D 1991 Mater. Chem. Phys. 271

Lokhande C D and Pawar S H 1982 Solid State Commun. 43 623

Lokhande C D and Pathan H M 2001a 10th National convention of electrochemists (Karaikudi: CECRI)

Lokhande C D and Pathan H M 2001b National seminar on current trends in materials science (Kottayam: Mahatma Gandhi University)

Lokhande C D, Ennaoui A, Patil P S, Giersig M, Muller M, Diesner K and Tributsch H 1998a Thin Solid Films 33070

Lokhande C D, Patil P S, Ennaoui A and Tributsch H 1998b Appl. Surf. Sci. 123/124 294

Lokhande C D, Sankapal B R, Pathan H M, Muller M, Giersig M and Tributsch H 2001 Appl. Surf. Sci. 181277

Lokhande C D, Pathan H M, Giersig M and Tributsch H 2002 Appl. Surf. Sci. 187101

Lundin A B and Kitaev G A 1965 Inorg. Mater. 12107

Madelung O 1984 Landolt-Bornsten (L. B. New Series) semiconductors: Physics of non-tetrahedrally bonded binary, compound III/ $17 \mathrm{~g}$ (Berlin: Springer Verlag)
Mandal K C and Savadogo O 1991 J. Mater. Chem. 1301

Maruno S, Yamada T, Noda M and Konda Y 1971 J. Appl. Phys. 10653

Mazanc, Muci J, Sa-Neto A, Ortz-conde A and Garcia F J 1991 Proc. 22nd IEEE PV Spe. Conf., p. 1156

Miller B and Heller A 1976 Nature 262680

Mitra P, Chatterjee A P and Maiti H S 1998a J. Mater. Sci. Mater. Electr. 941

Mitra P, Chatterjee A P and Maiti H S 1998b Mater. Lett. 35 33

Mondal A and Pramanik P 1983 J. Solid State Chem. 4781

Mondal A and Pramanik P 1984 J. Solid State Chem. 55116

Moss T S 1955 Proc. IRE 431869

Nair M T S, Guerrero L, Arenas O L and Nair P K 1999 Appl. Surf. Sci. 150143

Nascu C, Pop I, Ionescu V, Indrea E and Brata I 1997 Mater. Lett. 3273

Nicolau Y F 1985 Appl. Surf. Sci. 22/23 1061

Nicolau Y F and Minnard J C 1988 J. Cryst. Growth 92128

Nicolau Y F, Dupuy M and Brunel M 1988 J. Electrochem. Soc. 1281347

Nicolau Y F, Dupuy M and Brunel M 1990 J. Electrochem. Soc. 1372916

Okimura H, Matsumae T and Makabe R 1980 Thin Solid Films 7153

Olsen L C, Addis F W and Miller W 1983 Solar Cells 7247

Olvera M L, Maldonodo M, Asomoza R, Konagai M and Ssomoza M 1993 Thin Solid Films 299196

Padam G K 1987 Thin Solid Films 150 L-89

Paque H R, Linoc J R, Pinho and Losch W 1983 Proc. 9th photovoltaic solar energy conf., Freiburg, Germany, p. 3

Pathan H M 2002 Studies on chemical deposition and physicochemical properties of $\mathrm{Cu}$-In chalcogenide thin films, $\mathrm{Ph} . \mathrm{D}$. Thesis, Shivaji University, Kolhapur

Pathan H M and Lokhande C D 2001a DAE solid state physics symposium (Mumbai: Bhabha Atomic Research Centre)

Pathan H M and Lokhande C D 2001b Annual general meeting of Materials Research Society of India (MRSI), Kolkata

Pathan H M and Lokhande C D 2003a Advances in renewable energy technology (eds) S H Pawar and L A Ekal (New Delhi: Narosa Publishing House) p. 248

Pathan H M and Lokhande C D 2003b 14th AGM and theme symposium on novel polymeric materials (Mumbai: BARC)

Pathan H M, Sankapal B R and Lokhande C D 1999a National seminar on recent trends in mater. sci. (NERTMS-99), Tirupati

Pathan H M, Sankapal B R, Bagde G D and Lokhande C D 1999b 9th National convention of electrochemists (NCE-IX), Surat

Pathan H M, Salunkhe P V, Sankapal B R and Lokhande C D 2001a Mater. Chem. Phys. 72105

Pathan H M, Sartale S D, Bagde G D and Lokhande C D 2001b 15th International vacuum congress (IVC-15), AVS 48th International symposium (IVC-48), 11th International conference on solid surfaces (ICS-11) San Francisco, CA, USA

Pathan H M, Sankapal B R and Lokhande C D 2001c Indian J. Engg. Mater. Sci. 8271

Pathan H M, Sartale S D, Bagde G D and Lokhande C D 2001d 12th Annual general meeting of Materials Research Society of India (MRSI), Kolkata

Pathan H M, Bagade G D, Kale R B, Kulkarni S S and Lokhande C D 2002a National seminar on electro and magneto ceramics devices and systems, Akluj 
Pathan H M, Desai J D and Lokhande C D 2002b Appl. Surf. Sci. 20247

Pathan H M, Amalnerkar D P, Seth T and Lokhande C D 2003a Appl. Surf. Sci. 21148

Pathan H M, Amalnerkar D P, Seth T and Lokhande C D 2003b Appl. Surf. Sci. 218290

Patil S G and Fredgold R H 1971 J. Phys. D: Appl. Phys. 4718

Peter L M 1979 J. Electroanal. Chem. 9849

Pietrzyk D J and Frank C W 1974 Analytical chem: An introduction (New York: Academic Press)

Pramanik P and Biswas S 1986 J. Solid State Chem. 65145

Rai B P 1988 Solar Cells 25265

Rawson H 1967 Inorganic glass forming system: Nonmetallic solids (New York: Academic Press)

Reddy G B, Putta V, Panday D K and Chopra K L 1981 Solar Energy Mater. 5187

Reddy G B, Pandya D K and Chopra K L 1987 Solar Energy Mater. 15387

Resch R, Friedbacher G, Grasserbaur M, Kanniainen T, Lindroos S, Leskela M and Niinisto L 1997 Appl. Surf. Sci. 12051

Ristov M, Sinadinovski G J and Grozdanov I 1985 Thin Solid Films 12363

Ristov M, Sinadinovski G J, Grozdanov I and Mitreski M 1987 Thin Solid Films 14965

Ristov M, Sinadinovski G J and Mitreski M 1988 Thin Solid Films 167309

Said G and Lee P A 1973 Phys. Status Solidi (a)15 99

Salunkhe P V, Sankapal B R, Ahire R R and Lokhande C D 1999 9th National convention of electrochemists (NCE-IX), Surat

Sankapal B R, Mane R S and Lokhande C D 1999a J. Mater. Sci. Lett. 181453

Sankapal B R, Mane R S and Lokhande C D 1999b 10th Annual general meeting of the Materials Research Society of India, Bhopal

Sankapal B R, Pathan H M and Lokhande C D 1999c National seminar on recent trends in mater. sci. (NSRTMS-99), Tirupati

Sankapal B R, Mane R S and Lokhande C D 2000a Mater. Chem. Phys. 63226

Sankapal B R, Mane R S and Lokhande C D 2000b Mater. Chem. Phys. 63230

Sankapal B R, Mane R S and Lokhande C D 2000c Mater. Res. Bull. 352027
Sankapal B R, Ganesan V and Lokhande C D 2000d Indian J. Pure \& Appl. Phys. 38606

Sankapal B R, Mane R S and Lokhande C D 2000e Mater. Res. Bull. 35177

Sankapal B R, Pathan H M and Lokhande C D 2001 Indian J. Engg. \& Mater. Sci. 8223

Sartale S D and Lokhande C D 2000a Mater. Chem. Phys. 6563

Sartale S D and Lokhande C D 2000b Mater. Res. Bull. 35 1345

Sartale S D and Lokhande C D 2000c Indian J. Pure \& Appl. Phys. 3848

Sartale S D and Lokhande C D 2001a Mater. Chem. Phys. 7194

Sartale S D and Lokhande C D 2001b Mater. Chem. Phys. 72 101

Shafizade R B, Ivnova I V and Kazinets M M 1976 Thin Solid Films 35169

Shafizade R B, Ivanova I V and Kazinets M M 1978 Thin Solid Films $\mathbf{5 5} 211$

Skoog D J and West D M 1963 Fundamental of analytical chemistry (Holt Rinehart and Winston) 2nd ed.

Slater J C 1956 Phys. Rev. 1031931

Suarez R and Nair P K 1996 J. Solid State Chem. 123296

Sushiya K, Sugiyama I, Tachiyukai M, Kuse T, Nagoya Y, Okumura D, Sato M, Yamase O and Takeshita H 1996 Tech. Diag. of the Int. PVSEC-9, Miyazaki, Japan C-II-7

Tanaka K 1975 Appl. Phys. Lett. 26243

Tanaka K and Ohtsuka Y 1979 Thin Solid Films 5759

Tolstobrov E V and Tolstoi V P 1995 Russ. J. Appl. Chem. 68899

Tolstobrov E V, Tolstoi V P and Murin I V 2000 Inorg. Mater. 36904

Tolstoy V P and Molotilkina E V 1994 Russ. J. Inorg. Chem. 39372

Tolstoy V P and Ehrlich A G 1997 Thin Solid Films 30760

Tolstoy V P, Murin I V and Reller A 1997 Appl. Surf. Sci. 112 255

Toneje A and Toneje A M 1981 J. Solid State Chem. 39259

Valkonen M P, Kanniainen T, Lindroos S, Leskela M and Rauhala E 1997a Appl. Surf. Sci. 115386

Valkonen M, Lindroos S, Kanniainen T, Leskela M, Tapper U and Kauppinen E 1997b Appl. Surf. Sci. 12058

Watanbe K, Sato N and Miyuoka S 1983 J. Appl. Phys. 541256

Yesgude N S, Lokhande C D and Bhosale C H 1995 Thin Solid Films 263145 